\title{
Horasan Türkçesinin Deregez Ağzına Ait Bir Metin: Ellahekber'e Selām
}

\author{
Doç. Dr. Talip Doğan \\ Necmettin Erbakan Üniversitesi, Sosyal ve Beşeri Bilimler Fakültesi \\ Türk Dili ve Edebiyatı Bölümü \\ dogan.talip@gmail.com
}

Öz

Horasan Türkçesi, Türk dilinin Oğuz grubunun bir üyesidir. Horasan Türkçesini, İran'ın Kuzey Horasan ve Razavi Horasan eyaletlerinde konuşulan ağızlar topluluğu temsil etmektedir. Bu çalışmaya, bir Horasan Türkü olan Muhammed Arab Hedri'nin 2016 yılında yazmış olduğu Ellahekber'e Selām 'Allahuekber'e Selam' adlı şiir konu olmuştur. 109 kıtadan oluşan bu şiir, Şehriyâr'ın Héyder Baba'ya Selām adlı şiiri model alınarak yazılmıştır. Şair, söz konusu şiiri, Ellahekber dağıyla konuşmak suretiyle oluşturmuştur. Şiirde bir nostalji atmosferinde Deregez merkezli Horasan Türklügünün hayatı anlatılmaktadır. Ellahekber'e Selām şiirinin dili, Horasan Türkçesinin Deregez ağzına aittir. Çalışma kapsamında şiir, şairin ses kaydından hareketle çeviri yazı alfabesiyle yazılmıştır. Şiir, aynı zamanda Türkiye Türkçesine aktarılmıştır. Metnin sunduğu malzemeyle Deregez ağzının ses ve biçim bilgisi özellikleri ortaya konulmuştur. Deregez ağzında, Eski Oğuz Türkçesindeki "olga-bolga" dilli (karışık dilli) eserlerde olduğu gibi, bol-ve ol- fiilleri bir arada kullanılmaktadır.

Anahtar Kelimeler: Türk lehçeleri, İran Türk ağızları, Horasan Türkçesi, Deregez ağz1.

\section{A Text of the Dargaz Dialect from Khorasan Turkic: Ellahekber'e Selām}

\begin{abstract}
Khorasan Turkic is a member of the Turkic language Oghuz group. Khorasan Turkic is represented by a group of dialects spoken in the Northern Khorasan and Razavi Khorasan states of Iran. A poem called Ellahekber'e Selām "Selam to Allahuekber", written by a Khorasan Turk Muhammed Arab Hedri in 2016, has been the subject of this study. This poem, composed of 109 verses, is based on the poem of Şehriyâr's Héyder Baba'ya Selām. The poet created the poem by talking to mountain of Ellahekber. In the poetry, the life of Khorasan Turkishness from Dargaz is narrated in the atmosphere of nostalgia. The language of Ellahekber poem belongs to Dargaz dialect of Khorasan Turkic. Within the scope of the study, the poem was written in the transcription alphabet with reference to the voice recording of the poet. The poem was also transferred to Turkish. The phonetic and morphology features of the Dargaz dialect were revealed with the material presented by the text. Bol- and ol- verbs were used together in the text as in the studies with "olga-bolga" (mixed language) in Dargaz dialect from Old Oghuz Turkish.
\end{abstract}

Keywords: Turkic dialects, Turkic dialects of Iran, Khorasan Turkic, Dargaz dialect. 


\section{GİRIŞ}

İran'ın Kuzey Horasan ve Razavi Horasan eyaletlerinde konuşulan Horasan Türkçesi, Türk dilinin Oğuz grubunun bir üyesidir. Horasan Türkçesi bu bağlamda kimi tasnif çalışmalarında da zikredilmiştir. Oğuzcayı 5 kola ayıran Doerfer (1987, s. 247), Horasan Türkçesi ile Oğuz Özbekçesini bir grupta, Kuzeydoğu Oğuzca içinde yerleştirmiştir. Tekin (2005, s. 341)'in Oğuz ya da dağlı grubu olarak adlandırdığı bölümde Ana Türkçe kāal-fiiline göre Horasan Türkçesi, ġāl- alt grubunda (Türkmen Türkçesiyle birlikte) gösterilmiştir. Korkmaz (2003, s. LXXVII) da Güney-Batı Türkçesi adı altında Türkiye, Horasan, Azerbaycan, Türkmen ve Gagavuz Türkçeleri ile 5 lehçeyi kaydetmiştir.

Doerfer (1998, s. 274-275) tarafından ayrıca Horasan Türkçesi ağızları da tasnif edilmiştir. Şimdiki zaman ekleri ile bildirme (1. ve 2. şahıslar) ve emir (1. şahıslar) eklerindeki farklılıkların ölçüt alındığı tasnif şu şekildedir:

A. Şimdiki zaman ekleri:
(a) $-I y A$
(b) $-I r$
(c) $-A$

B. Bildirme ekleri:
(a) Kaşkay Türkçesindeki gibi $-(A) m,-(A) \eta$.
(b) (a)'ya benzer fakat çokluk 1. ve 2. şahıs ekleri -IK, -IGIs.
(c) Oğuz Özbekçesine (çokluk 1. şahıs -mIz) benzer biçimde gibi - $m A n$, -sAn
(d) $-m A n,-s A n$ ama çokluk 1 . şahıs -bIz.

C. Teklik ve çokluk 1 . şahıs emir ekleri:
(a) Azerbaycan Türkçesindeki gibi -Im, -AK.
(b) $-A m,-A K$ (teklik ve çoklukta aynı ünlüyle)
(c) -Im, -IK (teklik ve çoklukta aynı ünlüyle).
(d) $-I m,-\ddot{A} y l i$ veya benzer biçimler.

Bu ölçütlerden hareketle Horasan Türkçesinde 6 ağız grubu yer alır:

1. Kuzeybatı: Bocnurd vd.

2. Kuzey: Quçān vd.

3. Kuzeydoğu: Gucg1 vd.

4. Güney: Soltan-ābād vd.

5. Güneydoğu: Xarw-e Olyā vd.

6. Langar.

Tablo 1. Horasan Türkçesi ağızlarının özellikleri

Şimdiki zaman

(A)

$\begin{array}{ll}\text { Kuzeybatı } & -i y A \\ \text { Kuzey } & -A- \\ \text { Kuzeydoğu } & -A- \\ \text { Langar } & -A-\end{array}$

Bildirme

(B)

$-m$

$-m A n,-m I z$

$-m A n,-b I z$

$-m A n,-b I z$
Emir

(C)

$-I m,-A K$

$-I m,-A K$

$-I m,-A y l I$

$-I m,-A K$
Eklerdeki

farklılıkların

dağglımı

$\mathrm{Aa} \mathrm{Bb} \mathrm{Cc}$

$\mathrm{Ac} \mathrm{Bc} \mathrm{Ca}$

$\mathrm{Ac} \mathrm{Bc} \mathrm{Ca}$

$\mathrm{Ac} \mathrm{Bd} \mathrm{Ca}$ 


$\begin{array}{lllll}\text { Güney } & -I r- & -A m,-I K & -A m,-I K & \mathrm{Ab} \mathrm{Ba} \mathrm{Cb} \\ \text { Güneydoğu } & -I r- & -A m,-I K & -I m,-I K & \mathrm{Ab} \mathrm{Bb} \mathrm{Cc}\end{array}$

Doerfer'in tasnifine göre Deregez ağzl, Horasan Türkçesinin Kuzey grubuna dâhil olmaktadır. Nitekim bu ölçütler çerçevesinde Deregez ağzına ait olan bu metinde de şimdiki zaman eki -e, teklik ve çokluk 1. şahıs bildirme ekleri -men, -miz; teklik 1. şahıs eki -(I)m (y)im biçimlerinde geçmiştir: gelemen 'geliyorum' (80), deyilmen 'değilim' (DYY: 28), ġeribmiz 'garibiz' (104), baxım 'bakayım' (77), istim 'isteyeyim' (65), yolleyim 'yollayayım' (DYY: 25). Ancak çokluk 1. şahıs emir eki, -ey biçiminde (tasnif tablosunda ise $-A K$ ) kullanılmıştır: baxey 'bakalım' (54).

\section{ELLAHEKBER'E SELĀM HAKKINDA}

Bu çalışmaya konu olan Ellahekber'e Selām 'Allahuekber'e Selam' adlı şiir, bir Horasan Türkü olan Muhammed Arab Hedri ${ }^{1}$ tarafından yazılmıştır. Bu şiir esasında yazarın, Deregez Yār Yār adıyla 2016 yılında yazmış olduğu şiir kitabında yer almaktadır. 152 sayfadan oluşan şiir kitabı, İran'ın Kum şehrinde Yâs-i Behşâyiş yayınlarından Elçi Bey'in editörlüğünde yayımlanmıştır.

Deregez Yār Yār adlı eserde sayfa 4-6 arasında Mukaddime 'Giriş', sayfa 6-10 arasında Harf-i Dil-i Şāìr 'Şairin Gönül Sözleri' ve sayfa 10-16 arasında Maāarif-i Şehristān-ı Deregez 'Deregez Şehrinin Tanıtımı' bölümleri bulunmaktadır. Bu üç bölüm Farsça kaleme alınmıştır. Bu bölümlerin ardından Türkçe şiirlere yer verilmiştir. Sayfa 17-45 arasında dönèm dönèm 'Döneyim Döneyim', sayfa 46-64 arasında yār yār 'Yâr Yâr', sayfa 65-76 arasında dayı gizi 'Dayı Kızı' ve sayfa 77-139 arasında Ellahekber'e Selām 'Allahuekber'e Selam' başlıklarında yazılmış şiirler yer almaktadır. Eserde şiirlerin sunulmasında farklı yollar tercih edilmiştir. Türkçe şiirlerin ilk üçü, Farsça için kullanılan Arap temelli alfabe ve Azerbaycan Türkçesi için kullanılan Latin temelli alfabeyle bir arada yazılmıştır. En uzun şiir olan Ellahekber'e Selām 'Allahuekber'e Selam' ise sadece bölgede kullanılan Arap alfabesiyle yazılmış ve ardından her kıtanın Farsça açıklamaları verilmiştir. Diğer bir ifadeyle ilk üç şiirin Farsça açıklamaları, Ellahekber'e Selām 'Allahuekber'e Selam' şiirinin ise Latin temelli alfabeyle yazımı bulunmamaktadır. Eserde sayfa 140-149 arasında Tavzîhu'lLuggāt 'Kelimelerin Açıklamaları' ve son olarak sayfa 151'de Fihrist-i Menābi' 'Kaynakça' vardir.

\section{1. Yazım Özellikleri}

Şiirlerin Arap harfli yazımında bir kısım seslerin sistemli olarak işaretlendiği ve gösterildiği dikkati çekmektedir. Bu çerçevede /è/ (kapalı /e/) ile /o/ ve /ö/ ünlüleri yazımda ayırt edilmiştir. /è/ ünlüsü kelime başında /s/l, kelime içinde / / ile yazılmıştır. /o/ ünlüsü kelime başında / /و/, kelime içinde / / g/ ile; /ö/ ünlüsü ise kelime başında /ؤ/, kelime içinde / $/$ ile gösterilmiştir:

\footnotetext{
${ }^{1}$ Muhammed Arab Hedri, 1947 yılında İran'ın Razavi Horasan eyaletine bağlı Deregez şehrinde doğmuştur. Bu şehirde kültürlü bir ailede ve çevrede büyüyen Muhammed Arab Hedri'nin Türk diline daima özel bir sevgisi ve ilgisi olmuştur. Onu eserini yazmaya sevk eden de bu duyguları olmuştur. Muhammed Arab Hedri şu anda Deregez ve Lütfabad'da otel işletmeciliği yapmaktadır. Bir taraftan da kültürel faaliyetlerini sürdüren Muhammed Arab Hedri, Horasan bölgesindeki Türk atasözlerini derleyip yayımlamayı planlamaktadır.

Deregez şehri ise Razavi Horasan eyaletinin kuzeyinde ve Türkmenistan sınırına yakın bir yerde bulunmaktadır. Şehir, aynı adlı Deregez şehristanın yönetim merkezidir. Deregez, Horasan bölgesinin en büyük ve zengin şehirlerinden biri olarak bilinmektedir. Razavi Horasan eyaletinin merkezi olan Meşhed'e 266 km uzaklıktadır.

SEFAD, 2019; (41): 157-192
} 


\begin{tabular}{|c|c|}
\hline Çeviri Yazılı Yazım & Arap Harfli Yazım \\
\hline şād_èder 'şad eder' (8) & شاد ائدر \\
\hline yèrden 'yerden' (6) & 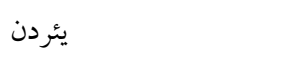 \\
\hline olsun 'olsun' (2) & 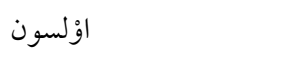 \\
\hline dolı 'dolu' (1) & دؤلى \\
\hline öziy ‘kendin' (21) & 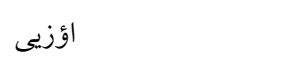 \\
\hline gözdendi 'gözdendir' (1) & 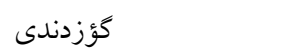 \\
\hline
\end{tabular}

Kelimelerde /ū/ ünlüsünün /وg/ile işaretlenmiş olması dikkat çekicidir. Bu kelimelerin bir kısmı şunlardır:

$\begin{array}{ll}\text { Çeviri Yazılı Yazım } & \text { Arap Harfli Yazım } \\ \text { sūlerdi 'sulardı' (22) } & \text { سولردئ }\end{array}$

Ön damak /k/ ve /g/ ünsüzleri de ayrıca işaretlenmiştir. /k/ ünsüzü /s/ ile, /g/ ünsüzü /ڤ/ile yazılmıştır:

$\begin{array}{ll}\text { Çeviri Yazılı Yazım } & \text { Arap Harfli Yazım } \\ \text { kéçende 'geçince' (5) } & \text { كئجندند } \\ \text { gédende 'gidince' (3) } & \end{array}$

\section{2. Edebî Değer}

Eserde 109 kıtadan oluşan Ellahekber'e Selām 'Allahuekber'e Selam' şiiri, özellikle dikkati çekici ve önemlidir. Kitabın editörü Elçi Bey, (Güney) Azerbaycan Türkçesi ile ġaranlıxda işıx gezenler adına 'karanlıkta ışık arayanlar adına' başlıklı, şiirin içeriği hakkında bilgiler veren ayrı bir ön söz yazmıştır (Arab Hedri, 2016, s. 71-76).

Bu şiir, Şehriyâr'ın Héyder Baba'ya Selām adlı şiirinden esinlenilip yazıldığı için bilhassa değerli addedilmiştir. Ellahekber'e Selām'a Muhammed Arab Hedri'nin de belirttiği üzere Şehriyar'ın bahsi geçen şiiri model olmuştur². Ellahekber, bölgede bir dağın adıdır. Şehriyar'ın yaptığı gibi, Muhammed Arab Hedri de şiirini Ellahekber dağıyla konuşmak suretiyle inşa etmiştir. Şiirde Deregez merkezli Horasan Türklerinin dünü ve bugünü, günlük pratikleri, sosyokültürel manzarası, meşhur simaları, iklimi, coğrafyası, yerleşim yerleri; şairin çocukluk günleri, dostları ve akrabaları bir nostalji atmosferinde konu edilmiştir. Şiirin çoğu bölümleri, söyleyiş ve içerik yönünden Héyder Baba'ya Selām'ın kıtalarıyla birebir benzerlik taşımaktadır. Bunu bir kıta ile örneklendirmek gerekirse:

\footnotetext{
${ }^{2}$ Şehriyâr'ın ilk defa 1954 yılında yayımlanan Héyder Baba'ya Selām adlı şiirinin başta İran'da yaşayan Türk grupları olmak üzere dünya Türkleri arasında çok sevildiği ve büyük yankı uyandırdığı bilinmektedir. Héyder Baba'ya Selām'ın saldığı sesin ve heyecanın tesiriyle İran'da yaşayan diğer Türk grupları da (Kaşkay, Horasan, Türkmen, Halaç gibi) aynı ruh ve duyuşla birçok şiir yazmışlardır. bk. Gökdağ \& Doğan (2016), Doğan (2018a).
} 
(5)

ellahekber, girgilleriy_üçende,

keklileriy çeşmeden sū içende,

nazlı toxlı, nenesinnen kéçende,

eger olse kéçenlerden bir yād_èt,

mehebbetli üregleri bir şād_èt.

Şehriyâr' $\mathrm{da}^{3}$ :

héyder baba, kehliklerin uçanda,

kôl dibinnen dovşan ġalxıp ġaçanda,

baxçaların çiçeklenip açanda,

bizden de bir mümkün olsa yad éle,

açılmıyan ürekleri şad éle.
Allahuekber, kartalların uçunca,

Kekliklerin çeşmeden su içince,

Nazlı toklu, annesinden geçince,

Eğer mümkünse geçenleri bir yâd et,

Muhabbetli yürekleri bir şad et.

Haydar Baba, kekliklerin uçunca,

Çalı dibinden tavşan kalkıp kaçınca,

Bahçelerin çiçeklenip açınca,

Bizi de bir mümkün olursa yâd et,

Açllmayan yürekleri şad et.

Şiirlerde kullanılan dil ise Horasan Türkçesinin Deregez ağzını temsil etmektedir. Yine, Muhammed Arab Hedri'nin kendisi de şiirlerini bu ağızla yazdığını bildirmiştir.

\section{DİL ÖZELLİKLERİ}

İncelemede şiirler, ağız bilimi çalışması kapsamında çeviri yazı alfabesiyle yazılırken ses kaydına başvurulmuştur. Bunun bir diğer sebebi de bölgede kullanılan alfabenin (Arap alfabesi) özellikle ses bilgisini yeterince yansıtmaması ve yazımlarda tutarsızlıkların bulunmasıdır. Çeviri yazı alfabesiyle yazılan metin, yanında Türkiye Türkçesine aktarılmıştır. Bununla beraber çalışmaya sözlük de eklenmiştir. Sözlük bölümünde, Türkiye Türkçesinde bulunmayan kelimeler ile fonetik ya da semantik açıdan değişmiş olan kelimelere yer verilmiştir. Çalışmada kelimeler alfabetik olarak dizilmiş, bunların anlamları da bağlama göre belirlenmiştir.

Metnin sunduğu malzemeden hareketle Deregez ağzının ses ve biçim bilgisi özellikleri ortaya konulmuştur. Ayrıca, biçim bilgisinin tespit edilemeyen az sayıdaki örnekleri ise eserdeki diğer şiirlerden alınmış ve sayfa numarasıyla sunulmuştur.

\section{1. Ses Bilgisi}

\section{1. 1. Ünlüler}

3. 1. 1. 1. Ünlü varlığında /a/, /e/, /é/, /1/, /i/, /o/, /ö/, /u/, /ü/ olmak üzere 9 adet ünlü yer alır. Ayrıca, birincil uzun ünlüler ile ses olayları sonucunda oluşan ikincil uzun ünlüler de vardır. Ünlüler arasındaki /è/ (kapalı /e/) ünlüsü, kelime köklerinde korunmuş ve yazımda da gösterilmiştir: yèt- 'ulaşmak' (3), yèr 'yer' (39), beş 'beş' (18), vèr- 'vermek' (24), géce 'gece' (80), gèy- 'giymek' (93), gèt- 'gitmek' (94), èt- 'etmek' (103), dè- 'demek' (86), èrte 'sonra' (80)4.

3. 1. 1. 2. Önlük-artlık uyumu sağlam değildir. Uyum içinde kullanılan unsurlar az sayıdadır. $\dot{I}_{-}(<e r-)$ fiili ile görülen ve duyulan geçmiş zaman ekleri bunlar arasındadır:

3 bk. Gökdağ ve Doğan, 2016, s. 42, 52.

4 İncelemede parantez içinde verilen numara, şiirin kıta numarasıdır.

SEFAD, 2019; (41): 157-192 


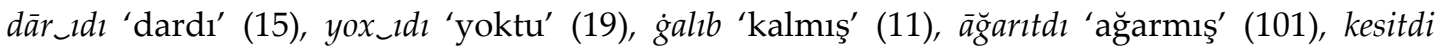
'kesmişs' (8), düşdi ‘düştü' (9), ġoydum 'koydum' (75).

Bunun dişında önlük-artlık uyumu, genellikle eklerin sadece ön ünlülü biçimlerinden dolayı bozulmuştur: dāğiy 'dağın' (4), oniy 'onun' (49), yuxarıye 'yukarıya' (71), aşşağaye 'aşağıya' (14), yazde 'baharda' (4), yande 'yanda' (11), yolden 'yoldan' (1), yuxarıden 'yukarıdan' (3), atnen 'at ile' (28), gezmağinen 'gezmek ile' (8), çağaler 'çocuklar' (11), bulutler 'bulutlar' (58), baxende 'bakınca' (4), unutmes 'unutmaz' (104), tanımes 'tanımaz' (104), olme'olmamak' (27), saten 'satan' (96), olse 'olsa' (5), durerdi 'dururdu' (42), vurèydim 'vuraydım' (13).

Kelimelerin kök veya tabanlarında yer alan ünlülerin öndamaksıllaşmasıyla uyum bozulmuştur: goce 'yaşlı' (27), āre 'ara' (42), buğde 'buğday' (43), ate 'baba' (64), izăg ' $\mathrm{uzak}^{\prime}$ (65), ġovurme 'kavurga' (36), yādle- 'hatırlamak' (6), bağle- 'bağlamak' (6), rāhet 'rahat' (100), palter 'elbise' (93).

Daima art ünlülü biçimiyle kullanılan -mağ eki, ön ünlülü kelimelerden sonra uyumu bozmuştur: götermă̆ 'götürmek' (17), dèmă̆ 'demek' (75), ètmă̆ 'etmek' (32).

3. 1. 1. 3. Bir kısım kelime tabanında düzlük-yuvarlaklık uyumu oluşmuştur: xatın 'kadın' (77), heniz < Far. henūz 'henüz' (106). Bunun dışında, düzlük-yuvarlaklık uyumu da sağlam değildir. Uyumun bozulmasına genellikle eklerin düz ünlülü biçimleri sebep olmuştur: oniy 'onun' (102), yolım 'yolum' (109), üzim ‘yüzüm' (13), yolı ‘yolu' (78), güli ‘gülü' (6), boğzımız 'boğazımız' (53), yurdımız 'yurdumuz' (65), gördim 'gördüm' (62), düşdiler 'düştüler' (32), durıtdı 'durmuş' (8), düş̧ibdile 'düşmüşler' (9), goydıler 'koydular' (25), göriy 'görün' (56).

3. 1. 1. 4. Şu kelimenin sonunda /a/ ünlüsü daralmamıştır5: aşşağa 'aşağ1' (14).

3. 1. 1. 5. Şu kelime asli biçiminde olduğu gibi /o/ ünlüsüyle kullanılır6: oyan'uyanmak' (6).

3. 1. 1. 6. Alıntı kelimelerde yer alan/a/ ünlüsü genellikle /e/ ya da /è/'ye değişmiştir: ġelb < Ar. kalb 'kalp' (1), vereğ < Ar. varak 'sayfa' (3), ġedim < Ar. ḳadîm 'eski' (7), rehmet < Ar. rahmet 'rahmet' (11), zehmet < Ar. zahmet 'zahmet' (16), eli < Ar. 'alî 'Ali' (18), ġed < Ar. ḳadd 'boy' (23), hereket < Ar. hareket 'hareket' (24), xeber < Ar. xaber 'haber' (26), hèyret $<$ Ar. hayret 'hayret' (9).

3. 1. 1. 7. Bazı Türkçe kelimelerde /1/ ve /u/ ünlüleri, /i/ olmuştur: çix- 'çıkmak' (36), girigi 'kartal' (5), yixil- 'yıkılmak' (55), yĭ̆iş- 'toplanmak' (68), iză̆ 'uzak' (1), diză̆ 'tuzak' (31).

3. 1. 1. 8. Şu kelimenin /u/ ünlüsü, /ü/'ye dönüşmüştür: üç- 'uçmak' (31).

3. 1. 1. 9. Arapça kökenli kelimede ayın /ع/ ünsüzünün düşmesiyle /ē/ ünlüsü oluşmuştur: bēzi < Ar. ba'z + Far. -i (izafet kesresi) (ba'zi > be'zi > bēzi) 'bazı' (29).

3. 1. 1. 10. Alıntı kelimelerde diş-dudak ünsüzü $/ v /$ nin düşmesi ile $/ \bar{o} /$ ünlüsü oluşmuştur. Bu kelimelerde /v/ ünsüzü, düz /a/ ve /e/ ünlülerini yuvarlaklaştırdıktan sonra düşmüştür: kōser < Ar. kevser (kevser > ḳōvser > ḳoser) 'Kevser' (17), nōruz < Far. nev-rūz

\footnotetext{
${ }^{5}$ bk. Tietze (2002, s. 214)' te aşă̆a < aşak- $a$ 'aşağı'. Eski Oğuz Türkçesinde aşağa 'aşağı' (Timurtaş, 2005, s. 131).

${ }^{6}$ krş. Azerbaycan Türkçesinde ve Türkmen Türkçesinde oyan- 'uyanmak' (Orucov vd 2006, s. 538; Tekin vd. 1995, s. 497).
} 
'Nevruz' (17), nōhe < Ar. nevhā 'ağıt' (26), dōre < Ar. devre 'devre' (34), ġōm < Ar. ḳavm 'kavim' (72), ġōgo

Diş-dudak ünsüzü $/ v /$ 'nin etkisiyle $a>0$ değişmesi Türkçe kelimelerde de meydana gelmiştir: govun 'kavun' (18), govurme 'kavurga' (36).

3. 1. 1. 11. Zarf-fiil eki $-(y) U b^{\prime}$ da $/ b /$ ünsüzünün sızıcılaşıp düşmesiyle /ū/ ünlüsü

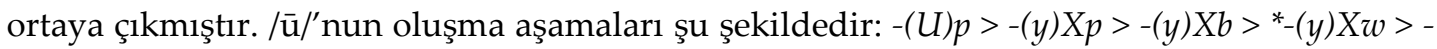

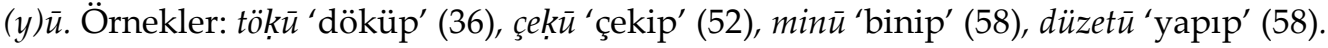

$/ \overline{\mathrm{u}} /$ ünlüsü benzer şekilde bir de $s \bar{u}$ 'su' (5) $(s u b>s u w>s \bar{u})$ kelimesinde oluşmuştur. $\mathrm{Bu}$ kelime, 3. kişi iyelik eki ya da belirtme durumu eki aldığında ise uzun ünlülü kullanılmamıştır. Bu durumda kelimenin /v/'li türevi kullanılmıştır: suvu '(onun) suyu' (21), suvu 'suyu' (52).

\section{1. 2. Ünsüzler}

3. 1. 2. 1. Kelime başı /k/ ünsüzü kimi kelimelerde korunmuştur: kęç- 'geçmek' (59), kölge 'gölge' (11), kö̧̧- 'göçmek' (109). Bunların haricinde kelime başı /k/ ünsüzü, ötümlüleşmiştir: gör- 'görmek' (3), göter- 'götürmek' (17), geç- 'geçmek' (32), gün 'güneş' (33), gèce 'gece' (37), gèt- 'gitmek' (50), gül- 'gülmek' (67).

3. 1. 2. 2. Bazı kelimelerde art ünlü yanında /ḱ (öndamaksıl $/ \mathrm{k} /$ ) ünsüzü kullanılmıştır7. béḱar 'işsiz' (21), tuḱan 'dükkân' (16), ḱasèb 'esnaf' (19).

3. 1. 2. 3. Kelime başı /ḳ/ ünsüzü, /g்/'ya dönüşmüştür: ġal- 'kalmak' (64), g่uş 'kuş' (91),

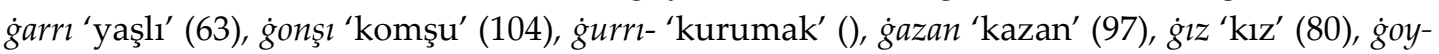
'koymak' (83), ġat- 'katmak' (100).

Doğu veya Batı kökenli kelimelerde ise / $/$ / ünsüzünün kullanılması karakteristiktir. Bu kelimelerde /ḳ/'nın kullanılması Farsçanın etkisiyledirs: kot 'kot' (24), taksi 'taksi' (28).

3. 1. 2. 4. Kelime içinde ve tek heceli kelimelerin sonundaki /ḳ/ ünsüzü, /x/ olmuştur: bax- 'bakmak' (54), yox 'yok' (82), çox 'çok' (29), ġırx- 'tıraş etmek' (72), yuxarı 'yukarı' (70), yuxu 'uyku' (49), yixil- 'yıkılmak' (55).

3. 1. 2. 5. Kelime başı /t/ ünsüzü, bazı kelimelerde korunmuştur: tut- 'tutmak' (83), tök'dökmek' (87), tik- 'dikmek' (24), tur- 'ayağa kalkmak' (59), tün 'dün' (102).

Bunların dışında /t/ ünsüzü, ötümlüleşip /d/ olmuştur: dāş 'taş' (3), dā̆g 'dağ' (4), dur'durmak' (8), düş- 'düşmek' (9), dè- 'demek' (23), der- 'dermek' (17), diză̆ 'tuzak' (31).

3. 1. 2. 6. Metinde bol-ve ol- fiilleri, bir arada kullanılmıştır. Ama bol- fiili 'bitmek, bitirmek, sona ermek' anlamlarında, ol- fiili ise 'olmak' anlamında ve daha çok yardımcı fiil özelliği ile kullanılmıştır9. Bölge ağzında her iki biçimin aynı zamanda kullanılması, farklı kavram alanlarını işaretlemesiyle mümkün olmuş görünmektedir: bu dunyāye bèl bağlamă̆ olmèydi 'Bu dünyaya bel bağlamak olmuyor' (64); feğet sabır yı̆̆lamağnen bolmèydi 'Fakat sabır

\footnotetext{
${ }^{7}$ krş. Türkiye Türkçesinde bekâr, dükkân (http://www.tdk.gov.tr).

8 İran'daki Türkçe değişkelerde /ḳ/ ünsüzünün gelişimi hakkında bk. Doğan (2018b).

9 Eski Oğuz Türkçesinde "olga-bolga" dilli (karışık dilli) adıyla anılan eserlerde de bol- ve ol-fiillerinin bir arada kullanıldığı burada hatırlanmalıdır (bk. Doerfer 1978, s. 150). Bu bakımdan Horasan bölgesindeki kimi Oğuz ağızlarının (Deregez ağzı gibi) "olga-bolga” dilli eserlerle benzerliği dikkat çekicidir. Deregez ağzında bol- fiilinin 'bitmek, bitirmek, sona ermek' gibi anlamlarda kullanılması, Türkmen Türkçesinde de söz konusudur. bk. Tekin vd. (1995, s. 77)'de bol- 'bitmek'.
}

SEFAD, 2019; (41): 157-192 
ağlamakla bitmiyor.' (64); omrımızı yaman günde boldıler. 'Ömrümüzü zor günlerde bitirdiler.' (107).

Kelime başı /b/ünsüzü, şu kelimelerde /v/ olmuştur ${ }^{10}$ : var 'var' (90), vèr- 'vermek' (24).

/b/ ünsüzü, şu kelimelerin ilkinde korunmuş, ikincisinde ötümsüzleşmiştir: birmă̆ 'parmak' (53), pişir- 'pişirmek' (71).

/b/ünsüzü şu kelimelerde /m/ olmuştur: men 'ben' (59), min- 'binmek' (79), miך 'bin' (DYY: 49).

Ayrıca, işaret zamiri ya da işaret sıfatı olan $b u$ kelimesinde /b/ ünsüzü, durum ekleriyle kullanıldığında /m/'ye değişmektedir. Bu değişme, çekim sırasında bir geniz ünsüzü olan zamir n'sinin etkisiyle gerçekleşmektedir: munde 'burada' (21), munnen ‘bundan' (50).

3. 1. 2. 7. Teklik ve çokluk 2. şahıs iyelik eki, ilgi durumu eki, teklik 2. şahıs görülen geçmiş zaman eki ve çokluk 2. şahıs emir eki gibi yapılarda bulunan /y/ ünsüzü, /y/'ye değişmiştir: ġelbiy '(senin) kalbin' (1), dereleriy '(senin) derelerin' (4), neney 'annen' (DYY: 20), bağiıiz 'bağınız' (DYY: 24), ġıziyiz 'kızınız' (DYY: 60), deregez'iy 'Deregez'in' (2), däğiy 'dağın' (4), göriy 'görün' (56), gédiy 'gidin' (75), ġaçurdiy 'kaçtın' (104).

/y/ ünsüzü, şu kelimede düşmüştür: söre < soฑra 'sonra' (53).

3. 1. 2. 8. Alıntı kelimenin başında /h/ ünsüzü düşmüştür: ava < Ar. hevā 'hava' (87.)

Ünsüzle biten kelimelerden sonra Farsça hem kelimesinde de /h/ ünsüzü düşer: gelin ġzzem 'gelin kız da' (90).

3. 1. 2. 9. Çokluk 1. şahıs görülen geçmiş zaman ekinde /k/ ünsüzü (dar ünlü /i/'den sonra) düşmüştür11: bilmedi 'anlamadık' (28), baxerdi 'bakardık' (12), üçerdi 'uçardık' (31), vurerdi ‘vururduk' (32).

2. 1. 2. 10. Bazı kelimelerin başındaki /y/ ünsüzü korunmuştur ${ }^{12}$ : yağaç 'ağaç' (92), yığla- 'ağlamak' (32).

Kelime başı /y/ ünsüzü, ilk hecesi dar ünlülü olan kimi kelimelerde ise düşmüştür: üz 'yüz' (13), üreg 'yürek' (5), igit 'yiğit' (15), ük 'yük' (44).

Ayrıca şu alıntı kelimenin içinde /y/ ünsüzü düşmüştür: kèf < Ar. keyf 'keyif' (31).

3. 1. 2. 11. Kimi kelimelerde ünsüz ikizleşmesi olmuştur: $i k k i$ 'iki' (100), teppe 'tepe' (107), ġarr 'yaşlı' (63), seg்gel 'sakal' (72), ġurrt- 'kurumak' (102),

Ünsüz ikizleşmesi alıntı kelimelerde de gerçekleşmiştir: yekke < Far. yek 'yalnız' (64), tezze < Far. tāze 'taze' (61).

3. 1. 2. 12. Şu kelimede yer değiştirme gerçekleşmiştir: torpa '̆ 'toprak' (55).

\footnotetext{
${ }^{10}$ Bu kelimeler Horasan Türkçesinin bazı ağızlarında ise /b/'lidir. Örneğin Bocnurd ağzında bār 'var', bèr- 'vermek' (Doğan, 2016, s. 36).

${ }^{11}$ Çokluk 1. şahıs görülen geçmiş zaman ekinin bu biçimde kullanılması Bocnurd ağzının da karakteristiğidir: gilerdi 'gülerdik', duymedi 'anlamadık', ġeyiddi 'döndük' (Doğan, 2016, s. 42).

12 krş. Eski Türkçede yığaç 'ağaç', yı̇̆la- 'ağlamak' (Ercilasun ve Akkoyunlu, 2014, s. 969-970).
} 


\section{2. Biçim Bilgisi}

\section{2. 1. İsimler}

3. 2. 1. 1. Çokluk eki, tek biçimli olarak +ler'dir: ildirimler 'yıldırımlar' (87), ġızler 'kızlar' (91), ḡöğaler 'kavgalar' (95).

\section{2. 1. 2. İyelik Ekleri:}

Tespit edilen iyelik ekleri $+(I) m$ (teklik 1. şahıs), $+(i) y \sim+(I) n^{13}$ (teklik 2. şahıs), $+(s) I$ (teklik 3. şahıs), +(I)mIz (çokluk 1. şahıs), +(i)yiz (çokluk 2. şahıs) biçimleridir: yolım 'yolum' (9), üzim 'yüzüm' (13), bāşım 'başım' (65), yādiy 'hatırın' (15), çeşmeleriy 'çeşmelerin' (6), neney 'annen' (DYY: 20), dā̆ğı 'dağı' (46), sedāsı 'sedası' (79), boyı 'boyu' (23), yurdımız 'yurdumuz' (65), boxçemiz 'bohçamız' (51), bağiyiz 'bağınız' (DYY: 24), g̀ıziyiz 'kızınız' (DYY: 60).

Ayrıca, bazı isim tamlamaları iyelik eki getirilmeden kurulmuştur: çèlle géce 'Çille gecesi' (37), ġiş géceler 'kış geceleri' (35), bahar günler 'bahar günleri' (38).

\section{2. 1. 3. Durum Ekleri:}

İlgi durumu eki $+(n)$ iy ve + In (az örnekte) biçimlerinde kullanılmıştır: kürekeniy 'damadın' (79), ġormeniy 'kavurganın' (35), xatınleriy 'kadınların' (89), kęçenleriy 'geçenlerin' (82), husèyn'in 'Hüseyin'in' (26).

İlgi durumu eki, teklik ve çokluk 1 . şahıs zamirinden sonra da +iy biçimindedir: meniy 'benim' (57), biziy 'bizim' (DYY: 21).

Belirtme durumu eki, ünsüzle biten isimlerden sonra $+I$; ünlüyle biten isimlerden sonra $+n I$ biçimlerindedir: yolı 'yolu' (8), çayı 'çayı' (37), dunyānı 'dünyayı' (27), dereni 'dereyi' (1).

3. şahıs iyelik ekli kelimelerden sonra bazen $+n$ biçimi kullanılmıştır: derextlerin 'ağaçlarını' (14), ġocelerin 'kocalarını' (14).

İyelik ekli kelimelerden sonra belirtme durumu, bazen de eksiz ifade edilmiştir: cānım aldı 'canımı aldı' (46).

Yönelme durumu eki, +(y)e biçimindedir: dāğe 'dağa' (3), toye 'düğüne' (70), yuxarrye 'yukarıya' (4), aşşă̆aye 'aşağıya' (14).

Şahıs zamirleri men ve sen'in yönelme durumu ekli biçiminde artdamaksıllaşma olmaz: sene 'sana' (44), mene 'bana' (DYY: 19).

Bulunma durumu eki +de biçimindedir: daşde 'taşta' (41), başınde 'başında' (51), bağde 'bağde' (54).

Ayrılma durumu eki, +den biçimindedir: yolden 'yoldan' (1), cevanlı̆̆den 'gençlikten' (11). Ek, /n/ ünsüzünden sonra ilerleyici benzeşmeyle +nen biçimine dönüşür: cenglerinnen 'cenklerinden' (2).

Vasita durumu eki, ünsüzle biten kelimelerden sonra +inen +nen, ünlüyle biten kelimelerden sonra ise +ynen biçimlerindedir: cavād'inen 'Cevat ile' (32), şōginen 'şevk ile' (23), atnen 'at ile' (28), bèlnen 'bel ile' (38), adiynen 'adıyla' (1), ġemçisiynen 'kamçısıyla' (28).

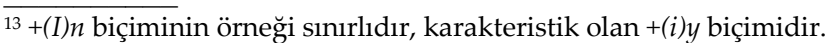


3. 2. 2. Soru zamiri olarak $h a<{ }^{*} \mathrm{xa}<{ }^{*} \mathrm{ḳa}^{14}$ 'ne, hangi' kelimesi kullanılmıştır: $h a$ yerrdesen? 'ne yerdesin (neredesin?)' (65).

\section{2. 3. Fiiller}

3. 2. 3. 1. Geniş Zaman: Geniş zaman ekleri -er+men (teklik 1. şahıs), -(y)er+sen (teklik 2. şahıs), -er (teklik 3. şahıs), -(y)el+ler < -(y)er-ler (çokluk 3. şahıs) biçimleriyle geçmiştir: görermen 'görürüm' (3), baxermen 'bakarım' (3), alermen 'alırım' (DYY: 33), dèyersen 'dersin' (29), yād_èder 'hatırlar' (8), vureller 'vururlar' (27), ağliyeller 'ağlarlar' (27).

Olumsuz geniş zaman eki -mes (teklik veya çokluk 3. şahıs) biçimindedir: bilmes 'bilmez' (10), çixmes 'çıkmaz' (15), tanımes 'tanımaz' (104).

3. 2. 3. 2. Şimdiki Zaman: Şimdiki zaman eki $-e+m e n ~ \sim-y+m e n$ (teklik 1. şahıs), -e+sen (teklik 2. şahıs), $-e+d i \sim-y+d i$ (teklik 3. şahıs), $-e+m i z$ (çokluk 1. şahıs) biçimlerinde geçmiştir ${ }^{15}$ : gelemen 'geliyorum' (80), istèmen 'istiyorum' (DYY: 41), vuresen 'vuruyorsun' (DYY: 28), açesen 'açıyorsun' (DYY: 39), gelesen 'geliyorsun' (DYY: 61), öpedi 'öpüyor' (DYY: 18), düşedi 'düşüyor' (DYY: 30), tutedi 'tutuyor' (DYY: 20), şarıllèydi 'şarıldıyor' (DYY: 54), èrtemiz 'götürüyoruz' (DYY: 61).

Olumsuz şimdiki zaman eki -méymen (teklik 1. şahıs), -méysen (teklik 2. şahıs), -méydi (teklik 3. şahıs) biçimindedir: açebilméymen 'açamıyorum' (DYY: 32), vérméymen 'vermiyorum' (DYY: 41), gelméysen 'gelmiyorsun' (DYY: 38), olméydi 'olmuyor' (64), bolméydi 'bitmiyor' (64), baxméydi'bakmiyor' (DYY: 20).

3. 2. 3. 3. Görülen Geçmiş Zaman: Görülen geçmiş zaman ekleri $-d X+m$ (teklik 1 . şahıs), $-d i+y$ (teklik 2. şahıs), $-d I$ (teklik 3. şahıs), $-d I$ (çokluk 1. şahıs), $-d I+(l e r)$ (çokluk 3. şahıs) biçimlerinde kullanılmıştır: aldım 'aldım' (62), üzlendim 'baktım' (1), goydum 'koydum' (75), düşdüm 'düştüm' (65), ġaçurdiy 'kaçtın' (104), ètdiy 'ettin' (DYY: 68), ġutardı 'tükendi' (52), geldi 'geldi' (9), görmedi 'görmedik' (28), bilmedi 'anlamadık' (28), goydıler 'koydular' (25), düşdiler 'düştüler' (32).

3. 2. 3. 4. Duyulan Geçmiş Zaman: Duyulan geçmiş zaman ekleri yerine $-I b+b e n$ (teklik 1. şahıs), $-X b+s A n$ (teklik 2. şahıs), $-X b \sim-I t d I \sim-I b d I$ (teklik 3. şahıs), $-I b d I+(l a)$ (çokluk 3. şahıs) biçimleri kullanılmıştır: aşıbben 'aşmışım' (10), ġaçıbben 'kaçmışım' (10), düşibben 'düşmüşüm' (10), düşibsen 'düşmüşsün' (9), ġalıb 'kalmış' (11), dağılıb 'dağılmış' (56), durıtdı 'durmuş' (8), kesitdi 'kesmiş' (8), dolıbdı 'dolmuş' (55), itibdi 'kaybolmuş' (55), düşibdile 'düşmüşler' (9).

3. 2. 3. 5. Şart: Şart eki tek biçimli -se (teklik 3. şahıs)'dir: olse 'olsa' (56), olmese 'olmasa' (27).

3. 2. 3. 6. İstek: İstek eki, -(y)e (teklik 3. şahıs) biçiminde bir örnekte tespit edilmiştir: oyane 'uyansin' (6).

3. 2. 3. 7. Emir: Emir ekleri $-(I) m \sim-(y)$ im (teklik 1. şahıs),-sXn (teklik 3. şahıs),-ey (çokluk 1. şahıs),-(y)iy (çokluk 2. şahıs) biçimlerinde kullanılmıştır: baxım 'bakayım' (77), olim 'olayım' (65), istim 'isteyeyim' (65), bağlèyim 'bağlayayım' (DYY: 24), yollèyim 'yollayayım' (DYY: 25), düzetsin 'düzeltsin' (9), selām_olsun 'selam olsun' (2), görey 'görelim' (21), baxey

\footnotetext{
${ }^{14}$ bk. kanta < ${ }^{*} k a+n+t a$ 'nerede' (Hamilton 2011, s. 181).

${ }^{15}$ Şimdiki zaman eki, -e biçiminde Horasan bölgesinde başka ağızlarda da (Zeyārat, Şirvān, Quçān, Şurak, Lotf-ābād gibi) kullanılmaktadır (bk. Doerfer, 1978, s. 170).
} 
'bakalım' (54), oley 'olalım' (65), göriy 'görün' (75), gédiy 'gidin' (75), saxliyiy 'saklayın' (56), yadliyiy 'yâd edin' (56), sipiriy 'süpürün' (DYY: 50).

3. 2. 3. 8. Geniş Zamanın Hikâyesi: Geniş zamanın hikâyesi -erdi+m (teklik 1. şahıs), (y)erdi -rdi (teklik 3. şahıs), -(y)erdi -rdi (çokluk 1. şahıs), -(y)erdi+(ler) -rdi+(ler) (çokluk 3. şahıs) biçimlerinde tespit edilmiştir: baxerdim 'bakardım' (106), yaterdim 'yatardım' (58), yağerdi 'yağardı' (84), dèyerdi 'anlatırdı' (23), söylerdi 'söylerdi' (77), sallerdi 'sallardı' (20), durerdi 'dururduk' (12), yığerdi 'toplardık' (30), oxurdıler 'çağırırlardı' (74), çalerdiler 'çalarlardı' (74), dèyerdiler 'söylerlerdi' (74).

3. 2. 3. 9. Duyulan Geçmiş Zamanın Hikâyesi: Duyulan geçmiş zamanın hikâyesi tek biçimli - $\bar{u} d i\left(<-\right.$ uvdi <-(I)bdi <-(I)p idi <-(I)p edi < *-(I)p erdi) yapısındadır ${ }^{16}$. Metinde $-\bar{u} d i$ (teklik 3. şahıs) biçimi kullanılmıştır: gèdūdi 'gitmişti' (103), nāxoş_olüdi ‘hastalanmıştı' (103), dèyūdi 'demişti' (104), alūdi 'almıştı' (104).

3. 2. 3. 10. İsteğin Hikâyesi: İsteğin hikâyesi -èyditm (teklik 1. şahıs) biçiminde kullanılmıştır: duréydim 'duraydım' (13), vuréydim 'vuraydım' (13), atèydim 'ataydım' (13).

3. 2. 3. 11. Bildirme Ekleri: Bildirme ekleri olarak -men (teklik 1. şahıs), -sen (teklik 2. şahıs), -di (teklik veya çokluk 3. şahıs), -miz (çokluk 1. şahıs) biçimleri kullanılmıştır ${ }^{17}$ : gülimen 'gülüyüm' (DYY: 59), deyilmen 'değilim' (DYY: 28), gelinsen 'gelinsin' (DYY: 49), yerrdesen 'yerdesin' (65), belenddi 'yüksektir' (7), gelindi 'gelindir' (29), yadlerdedi 'hatıralardadır' (36), ġeribmiz 'garibiz' (104).

3. 2. 3. 12. Sıfat-Fiil Ekleri: Metinde sıfat-fiil ekleri olarak -(y)en ve -meli biçimleri geçmiştir: düyü saten tikan 'dügü satan dükkân' (96), güller tekin görmelidi bu sehne 'güller gibi görmeye değer bu sahne' (88).

Metinde -(y)en, "-DXK" sıfat-fiil ekinin işleviyle de kullanılmıştır. Ayrıca, -(y)en'in bu işleviyle kurulan isim tamlamalarında tamlayan unsuru eksizdir: atam zehmet çeken günler 'babamın zahmet çektiği günler' (54), ġı, oğlanler bextin açen günidi 'kızların, oğlanların bahtının açıldığı gündür' (94).

3. 2. 3. 13. Zarf-Fiil Ekleri: Metinde kullanılmış olan zarf-fiil ekleri -(y)ende, -(y)Xb, (y) $\bar{u}(<-(\mathrm{y}) \mathrm{Xb}$ ) biçimleridir: çalende 'çalınca' (106), yẻtende 'ulaşınca' (3), tutub 'tutup' (27), töḳu 'döküp' (36), dèyū 'deyip' (38), ġaz̄u 'kazıp' (39), yuxu görū 'rüya görüp' (58).

3. 2. 4. Çekim Edatları: Metinde için çin 'için', kimin 'gibi', tek tekin 'gibi', söre 'sonra' çekim edatları kullanılmıştır: kişmiş_için 'kuru üzüm için' (30), düzetmağçin 'düzeltmek için' (42), olar için 'onlar için' (48), memleketçin 'memleket için' (99), şamal kimin 'rüzgâr gibi' (31), kefter kimin 'güvercin gibi' (90), yuxu tek 'uyku gibi' (49), mecnun tekin 'Mecnun gibi' (46), güller tekin 'güller gibi' (88), onnen söre 'ondan sonra' (53).

3. 2. 5. Pekiştirme Edatları: Metinde $e m \sim$ yem $<$ Far. hem 'da de' unsurları kelime ya da kelime gruplarını pekiştirmede kullanılmıştır. Ünsüzle biten kelimelerden sonra em, ünlüyle biten kelimelerden sonra yem unsuru getirilir: elliden_em 'elliden de' (10), gelin ġı_em 'gelin kız da' (90), çağa yem 'çocuk da' (102), her biri yem 'her biri de' (32).

\footnotetext{
${ }^{16}$ Duyulan geçmiş zamanın hikâyesinde - $\bar{d}$ i biçimi, Bocnurd ağzında da kullanılmaktadır (bk. Doğan, 2017).

17 Bildirme ekleri, Özbek Türkçesinde de benzer biçimlerdedir: yoxshi-man 'iyiyim', yoxshi-san 'iyisin', yoxshi-dir 'iyidir', yoxshi-miz 'iyiyiz', vd. (bk. Öztürk, 2016, s. 64).
}

SEFAD, 2019; (41): 157-192 


\section{SONUC}

Son yıllarda, Horasan Türkleri ana diliyle edebî eserler ortaya koymaktadırlar. Bu teşebbüsler her şeyden önce, İran'da Farsçanın kıskacında yok olma tehlikesiyle karşı karşıya olan Horasan Türkçesi adına değerlidir. Horasan Türkleri arasında Türkçe yazma akımının oluşmasında Şehriyar'ın Héyder Baba'ya Selām adlı şiirinin önemli rolü bulunmaktadır. Bu çalışmada ele alınan Ellahekber'e Selām şiiri de bunlardan biridir. Muhammed Arab Hedri, şiirini Ellahekber dağıyla konuşmak suretiyle oluşturmuştur. Şiirde çok yönlü şekilde Horasan Türklügünün hayatı işlenmiştir. Ellahekber'e Selām şiiri, Horasan Türkçesinin Deregez ağzıyla söylenmiştir.

Oğuz grubunda yer alan Horasan Türkçesi, diziliş açısından Azerbaycan ve Türkmen Türkçeleri arasındaki halkayı oluşturmaktadır. Bir başka deyişle Horasan Türkçesi, kimi özellikleriyle Azerbaycan Türkçesine, kimi özellikleriyle de Türkmen Türkçesine yaklaşmaktadır. Horasan Türkçesi, diğer taraftan da Özbek Türkçesiyle benzer özellikler taşımaktadır. Örneğin; (Horasan Türkçesinin) Deregez ağzında kelime içinde ve tek heceli kelimelerin sonundaki / $/$ ünsüzü, /x/ olmuştur: bax- 'bakmak', yuxarı 'yukarı' vb. Şahıs zamirleri men ve sen'in yönelme durumu ekli biçiminde artdamaksıllaşma olmamaktadır: mene 'bana', sene 'sana'. Bu özellikler, Azerbaycan Türkçesinin de karakteristiğidir. Kelime başı /b/ ünsüzü, Deregez ağzında /v/ olmuştur (var 'var', vèr- 'vermek' gibi); (Horasan Türkçesinin) Bocnurd ağzında ise Türkmen Türkçesinde olduğu gibi korunmuştur (bār 'var', bèr- 'vermek' gibi). Deregez ağzında teklik ve çokluk 1. şahıs bildirme ekleri -men, -miz biçimlerindedir: gülimen 'gülüyüm', geribmiz 'garibiz'. Özbek Türkçesinde bu ekler benzer biçimde -man, -miz'dir.

Ayrıca, Eski Oğuz Türkçesinde karşılaşılan "olga-bolga" dilli (karışık dilli) eserlerin dilinin yorumlanmasında Horasan Türkçesi ağızları önemli veriler sunmaktadır. Ellahekber'e Selām'da bol- ve ol- fiillerinin bir arada kullanılması bu bağlamda kaydedilmesi gereken özelliklerdendir.

\section{SUMMARY}

Khorasan Turkic is a member of the Turkic language Oghuz group. Khorasan Turkic is represented by a group of dialects spoken in the Northern Khorasan and Razavi Khorasan states of Iran.

In recent years, the Khorasan Turks have produced literary works with their mother tongue. These undertakings are, above all, valuable in the name of Khorasan Turkic, which is in danger of disappearing under the pressure of Persian in Iran.

The poem called Ellahekber'e Seläm "Selam to Allahuekber" has been the subject of this study, which was written by a Khorasan Turk Muhammed Arab Hedri. This poem is in the book of poetry named Deregez Yār Yār written in 2016. Different ways were preferred for presenting poems in the work. The first three of the Turkic poems were written together with the Arabic based alphabet used for Persian and the Latin based alphabet used for Azerbaijan. The longest poem, Ellahekber'e Selām "Selam to Allahuekber" was written only in the Arabic alphabet used in the region, followed by Persian descriptions of each verse.

In the formation of the Turkic writing movement among the Khorasan Turks, the poem Héyder Baba'ya Selām by Şehriyâr has an important role. One of these is the poem of Sllahekber'e Selām. Muhammed Arab Hedri created the poem by talking to mountain of 
Allahuekber. In the poetry, the life, daily routines, socio-cultural views, famous characters, climate, geography and places of Khorasan Turks from Dargaz and childhood, friends and relatives of the poet are narrated in the atmosphere of nostalgia. Most parts of the poem have a similarity to the verses of Héyder Baba'ya Selām in terms of utterance and content. The language of Ellahekber'e Selām poem belongs to Dargaz dialect of Khorasan Turkic.

Khorasan Turkic in the Oghuz group constitutes the ring between Azerbaijan and Turkmen Turkic in terms of order. In other words, Khorasan Turkic is similar to Azerbaijani Turkic with some characteristics and to Turkmen Turkic with some other characteristics. Khorasan Turkic, on the other hand, has similar characteristics with Uzbek Turkic. For example; (Khorasan Turkic) / $/$ / consonant at the end of the single syllable words and in the words has been $/ \mathrm{x} /$ in Dargaz dialect: bax- 'to look', yuxar 'up' and so on. Dative form of personal pronouns men and sen are not transformed into post-palatalization in the form of affixed: mene 'me', sene 'you'. These characteristics are characteristic of Azerbaijan Turkic. The beginning of the word $/ \mathrm{b} /$ consonant became $/ \mathrm{v} /$ in Dargaz dialect (for example var 'there is', ver- 'to give'); (Khorasan Turkic) it was saved in Bocnurd dialect as in Turkmen Turkic ( $b \bar{a} r$ 'there is, berr- 'to give'). Singular and plural first personal pronouns in Dargaz dialect are -men, -miz: gülimen 'I am its rose', geribmiz 'we are strange'. In Uzbek Turkic, these suffixes are similarly -man, -miz.

In addition, in the interpretation of the language of "olga-bolga" (mixed language) works in Old Oghuz Turkic, Khorasan Turkic dialects present important data. In this context, the use of bol- and ol- together in Ellahekber'e Selām should be recorded as an important characteristic. 


\section{KAYNAKÇA}

“Güncel Türkçe Sözlük". http://www.tdk.gov.tr/ (Erişim tarihi: 2 Ekim 2018).

Arab Hedri, M. (2016). Deregez yār yār. Kum: Yâs-i Behşâyiş Yayınları.

Atıcı, A. (2018). İran Türk değişkelerindeki var/yok + iyelik yapısı üzerine eşzamanlı bir inceleme. Türkbilig, 35, 165-180.

Doerfer, G. (1978). Das chorasantürkische. TDAY-Belleten, 1977, 127-204.

Doerfer, G. (1987, Kasım). İran'da Türkler. Türk Dili, 431, 242-251.

Doerfer, G. (1998). Turkic languages of Iran. In L. Johanson \& É. Á. Csató (Ed.), The Turkic Languages (pp. 273-282). London \& New York: Routledge.

Doğan, T. (2016). Ġeşeng Ginle-Horasan Türkçesi üzerine bir inceleme. Ankara: Akçağ Yayınları.

Doğan, T. (2017). Horasan Türkçesinin Bocnurd ağzında $\{-(1) d d 1(r)\}$ ve $\{$-ūdi\} yapıları. Modern Türklük Araştırmaları Dergisi, 14 (2), 41-55.

Doğan, T. (2018a). İran Türklerinde 'Héyder Baba'ya Selām'ın etkisiyle yazılan şiirlerdeki ortaklıklara dair. Yeni Türkiye (Türk Dili Özel Sayısı-I), 99, 497-515.

Doğan, T. (2018b). İran'daki Türkçe değişkelerde k (art damak k'si) ünsüzünün gelişimi. XIII. Uluslararası Büyük Türk Dili Kurultayı Bildirileri Kitabı (s. 15-25) İçinde. Varşova/Polonya.

Gökdağ, B. A. ve Doğan, T. (2016). İran'da Türkler ve Türkçe. Ankara: Akçağ Yayınları.

Hamilton, J. R. (2011). İyi ve kötü prens öyküsü. (V. Köken, çev.). Ankara: TDK Yayınları.

Kâşgarlı Mahmud (2014). Dîvânu Lugâti't-Türk (Giriş-Metin-Çeviri-Notlar-Dizin). A. B. Ercilasun ve Z. Akkoyunlu (Yay. Haz.). Ankara: TDK Yayınları.

Korkmaz, Z. (2003). Türkiye Türkçesi grameri (şekil bilgisi). Ankara: TDK Yayınları.

Orucov, E. vd. (2006). Azerbaycan dilinin izahlı lüğeti. Bakü: Milli Elimler Akademiyası.

Öztürk, R. (2016). Özbek Türkçesi el kitabı. Konya: Palet Yayınları.

Tekin, T. (2005). Türk dil ve diyalektlerinin yeni bir tasnifi. Makaleler 3: Çağdaş Türk Dilleri İçinde (s. 319-342). Ankara: TDK Yayınları.

Tekin, ve diğerleri. (1995). Türkmence-Türkçe sözlük. Türk Dilleri Araştırmaları, 8, Ankara: Simurg Yayınları.

Tietze, A. (2002). Tarihi ve etimolojik Türkiye Türkçesi lugatı (Birinci Cilt A-E). İstanbul: Simurg Yayınları.

Timurtaş, F. K. (2005). Eski Türkiye Türkçesi. Ankara: Akçağ Yayınları. 


\section{EKLER}

\section{1-ÇEVİRI YAZI İŞARETLERİ VE KISALTMALAR}

/è/ kapalı /e/ ünlüsü

/ā/ uzun /a/ ünlüsü

/ē/ uzun /e/ ünlüsü

/î/ uzun /i/ ünlüsü

/ō/ uzun /o/ ünlüsü

/ $/ \overline{\mathrm{u}} / \quad$ uzun $/ \mathrm{u} /$ ünlüsü

/g/ art damak /g/ ünsüzü

/ḱk/ ön damak /k/ ünsüzü (art ünlünün yanında)

/x/ $\quad \operatorname{art}$ damak $/ \mathrm{h} /$ ünsüzü

/ḳ/ art damak / / ünsüzü

$/ \mathrm{n} / \quad$ damak $/ \mathrm{n} /{ }^{\prime} \mathrm{si}$

I'/ Ayın $/ \varepsilon /$ 'lı kelimelerde kesme bildirir.

- Ulama bildirir.

$>\quad$ Bu şekle gider.

$<\quad$ Bu şekilden gelir.

* Tanıklandırılamamışş şekil.

- $\quad$ Fiil kök ve gövdesine gelen ek.

+ $\quad$ İsim kök ve gövdesine gelen ek.

Ar. Arapça

Far. Farsça

DYY Deregez Yār Yār, bk. Arap Hedri (2016). 


\section{2-METIN VE AKTARMA (TÜRKIYYE TÜRKÇESİ)}

ellahekber'e selām

(1)

iză̆ yolden yurdımıze üzlendim, deregez, dov, dă̆, dereni tovlendim, ellahekber adiynen men sözlendim, ellahekber, ġelbiy dolı sözdendi, baxmă̆leriy mehebbetli gözdendi.

(2)

selām_olsun, ellahekber dāğ̆ıne,

selām_olsun, deregez'iy_ädıne, selām_olsun, milletiniy diline, deregez'iy tārixde bir ādı var, îran turan cenglerinnen yādı var.

ellahekber, dāşlı dāğe yètende, tovlı yolı yuxarlye gédende, yuxarıden deregez'i görende, tārixi, men vereğ vereğ görermen, bendèyān'e, nādèr'e men baxermen.

(4)

ellahekber, yuxarnye baxende, tovl yolı sennen_üste çixende, dereleriy yazde bulut tutende, selām_olsun, belend dāğiy_ādıne, cevanleriy ādı gelsin yādıne.

(5)

ellahekber, girgileriy_üçende, keklileriy çeşmeden sū içende, nazlı toxlı, nenesinnen kèçende, eger olse kèçenlerden bir yād_èt, mehebbetli üregleri bir şād ¿èt.

(6)

ellahekber, yă̆̆ış seni yādlesin, çeşmeleriy dāem yèrden ġeynesin, çă̆aleriy deste güli bağlesin, şamaliynen issi gelsin bu yane, üreydeki mehebbetler oyane.

(7)

ellahekber, gulleleriy belenddi, çeşmeleriy yèrden däèm gelendi, seniy_adiy, gedimlerden galand,, iran turan ġesseleri, galand,,
Allahuekber'e Selam

Uzak yoldan yurdumuza baktım, Deregez'i, vadiyi, dağı ve dereyi gezdim, Allahuekber adıyla ben sözlendim, Allahuekber, kalbin doludur sözle, Bakışların muhabbetli gözdendir.

Selam olsun, Allahuekber dağına, Selam olsun, Deregez'in adina, Selam olsun, milletinin diline, Deregez'in tarihte bir adı var, İran-Turan cenklerinden bir hatırası var.

Allahuekber, taşlı dağa ulaşınca, Kıvrımlı yoldan yukarıya gidince, Yukarıdan Deregez'i görünce, Tarihi, ben sayfa sayfa görürüm, Bandiyan ${ }^{18^{\prime}} \mathrm{a}$, Nadiri' ${ }^{19}$ e ben bakarım.

Allahuekber, yukarıya bakınca, Kıvrımlı yoldan yamaçlara çıkınca, Derelerin baharda bulutlanınca, Selam olsun, yüce dağın adına, Gençlerin adı gelsin hatırına.

Allahuekber, kartalların uçunca, Kekliklerin çeşmeden su içince, Nazlı toklu, annesinden geçince, Eğer mümkünse geçenleri bir yâd et, Muhabbetli yürekleri bir şad et.

Allahuekber, yağmur seni hatırlasın, Çeşmelerin daima yerden kaynasın, Çocukların deste gülü bağlasın, Rüzgârın kokusu gelsin bu yana, Yürekteki muhabbetler uyansın.

Allahuekber, tepelerin yüksektir, Çeşmelerin daima yerden çıkmıştır, Senin adın eskilerden kalmıştır, İran-Turan kıssaları kalmıştır, 
rustem kesen, gez yağacı, yalandī?

(8)

şuturperan, yuxarıde durttdl, tîzî sèyyèd, yolı mekem kesitdi, yuxariden bulutlere baxitd, adlu dă̆gl, dost_o refiğ yād_èder, gezmağinen üreyini şād_èder. yolım sennen iză̆ düşdi hicrete, tivan geldi, sen düşibsen ġurbete, kebğān, geptî düşibdile hèyrete, bir kimse yox, köhne yolı düzetsin, duābi'nı, deregez'e yètirsin.

ellahekber, sennen iză̆ düşibben, umur kéçdi, elliden_em aşıbben, cevanliğde her yana men, ġaçıbben, bilmes_idim ġucalı̆ var, ġalmă̆ var, cevanliğden bir ġuru ād ġalmă̆ var.

ellahekber, ata gètdi rehmete, çă̆aleri ezeb ġalib, zehmete, her biri bir yande galib xidmete, ata, nene kölgesi ayrn zatdl, mehebbetli baxmağı ayrı zatdl.

kiçiliğde küçelerde durerdi, ellahekber, sene eceb baxerdi, maşınleriy çırāğıni görerdi, xoşallığden birden feryād çekerdi, şadlığı biz üreylere tökerdi.

ellahekber, āb germ'iyde durèydim, issi sūden men üzime vurèydim, girx ġız'iyde yéddi daşı atèydim, şāyed ki men ārézūme yètèydim, bu mélletiy şadlığını görèydim. xenteme'niy köteline yètèydim, deregez'iy derextlerin göréydim,
Rüstem'in ağacı kesmesi yalan mı?

Şuturperan ${ }^{20}$, yukarıda durmuş, Tîzî Seyyid ${ }^{21}$, yolu sağlam kesmiş, Yukarıdan bulutlara bakmış, Namlı dağı dost ve arkadaş yâd eder, Gezerek yüreklerini şad eder.

Yolum senden uzak düştü hicrete, Tivan $^{22}$ geldi, sen düşmüşsün gurbete, Kebgan ${ }^{23}$, Gepti ${ }^{24}$ düşmüşler hayrete, Bir kimse yok, eski yolu düzeltsin, Duab1 ${ }^{25}{ }^{\prime} y 1$, Deregez'e ulaştırsın.

Allahuekber, senden uzak düştüm, Ömür geçti, elliden de aştım, Gençlikte her yana ben, kaçtım, Bilmezdim yaşlılık var, kalmak var, Gençlikten bir kuru adın kalması var.

Allahuekber, baba gitti rahmete, Çocukları azaba kaldı, zahmete, Her biri bir yanda kald, hizmete, Baba, anne gölgesi ayrı şeydir, Muhabbetli bakması ayrı şeydir.

Çocuklukta sokaklarda dururduk, Allahuekber, sana acayip bakardık, Arabaların 1şıklarını görürdük, Mutluluktan birden feryat ederdik, Mutluluğu biz yüreklere dökerdik.

Allahuekber, Âb Germ ${ }^{26}$ inde duraydım, Sıcak sudan ben yüzüme vuraydım, Kırk Kız'ında yedi taş ataydım, Eğer ki ben arzuma ulaşaydım, Bu milletin mutluluğunu göreydim.

Henteme'nin tepesine ulaşaydım, Deregez'in ağaçlarını göreydim,

\footnotetext{
${ }^{20}$ Yol adi.

21 Yol ad1.

${ }^{22}$ Yol adi.

23 Köy ad1.

${ }^{24}$ Köy adı.

${ }^{25}$ Köy ad1.

${ }^{26}$ Çeşme adı (<Far. āb germ 'sıcak su').

SEFAD, 2019; (41): 157-192
} 
bazarınde aşşă̆aye gédèydim, bir de gene gocelerin görèydim, mehebbetiy tamaşaye durèdim.

(15)

deregez'iy küçeleri dār ¿ıdı, durust kasıb tuḱanlerde vār_ıdı, dost_o refiğ, birbirine yār $\_\imath d \imath$, yādiydedi gocaleriy adlerî? yādden çixmes igitleriy yādleri.

(16)

kelbi islam, tuḱanını açerdi, bedel_emi, yaxçı ġatı̆̆ saterdi, suleyman bey, sibilini tōlerdi, durustliğnen ḱasıblığiy zehmeti, hudāvendiy lutfi, bîxed rehmeti.

bedel_emi, küçede dād çekerdi, kelbi kōser, xéyarleri sererdi, nōruz memmed, yaxçllerin dererdi, sebzi, mîve, yaxçısini götermă̆g, müşterini razı ève göndermă̆.

ebdul_eli, xèyar bugün néçedi? xāgan govun, babaxarman neç̧edi? bağden gelen yaxçı üzim néçedi? temām biri, batmanı bir, beş ġerān, munnen erzan sen istisen xoş zebān?

celal ă̆a, butg்esinde durerdi, ebbas_eli, bestenisin tōlerdi, ă̆a çayçı, ġelyanını küflerdi, nādurusliğ, bu milletde yox $\imath d \imath$, kaséblerde doğru dèmağ çox—ıdı. (20)

eli murād, sebzileri dererdi,

ikkisini otuz pule saterdi, sarèmsağiy ġozesini sallerdi, seher çă̆gl, bazarde bir ālemdi, gem_o gंusse, ġyā munde yalandı.

gülriz'deki bağlerde kimler vardi, sèlavada oniy suvu kem vard,,
Pazarında aşağıya gideydim,

Bir de yine kocalarını göreydim,

Muhabbetin seyrine duraydım.

Deregez'in sokakları dardı, Dükkânlarda dürüst esnaf vardı, Dost ve arkadaş, birbirine yârdi, Hatırında mıdır kocaların adları? Hatırlardan çıkmaz yiğitlerin hatıraları.

Kelbi İslam, dükkânını açardı, Bedel Emmi, güzel yoğurt satard1, Süleyman Bey, bıyığını kıvırırdı, Dürüstlükle esnaflığın zahmeti, Yaradan'ın lütfu, sınırsız rahmeti.

Bedel Emmi, sokakta bağırırdı, Kelbi Kevser, salatalıklarını sererdi, Nevruz Muhammet, iyilerini seçerdi, Sebze, meyve iyisini götürmek, Müşteriyi, eve razı göndermek.

Abdul Ali, hıyar bugün nasıldır?

"Hakan 27" kavun, "babaharman 28" nasıldır?

Bağdan gelen güzel üzüm nasıldır?

Hepsi, batmanı bir, beş "gıran ${ }^{29 ",}$

Bundan daha uygun tatlı dil mi istersin?

Celal Ağa, büfesinde dururdu,

Abbas Ali, dondurmasını döndürürdü,

Çaycı ağa, nargilesini üflerdi,

Sahtekârlık bu millette yoktu,

Esnafta doğruluk çoktu.

Ali Murat, sebzeleri dererdi,

İkisini otuz pula satard1,

Sarımsağın kabuğunu sallardı,

Seher vakti, pazar bir âlemdir,

Gam ve kasvet, sanki burada yalandır.

Gülriz'deki bağlarda kimler vardır,

Selavada ${ }^{30}$ az su vardır,

\footnotetext{
${ }^{27}$ Kavun çeşidi.

${ }^{28}$ Kavun çeşidi.

${ }^{29}$ Para birimi.

${ }^{30}$ Irmak adi.
} 
çeǵğ̊rlı'niy üreyime ya dardı? xuday öziy olare bir rehm, görey, béḱarlı̆̆ı sūsızlığı kes, görey.

(22) mestū supur, küçeleri sūlerdi, ferū neccar, erresini çekerdi, gürüzli yem badımcanı tökerdi, helal loğma çixarmă̆iy ġaçmă̆ şirinlığı üreylere tökmă̆g.

(23) nōruz emi, bize nă̆ıl dèyerdi, abg்uşt etin bir şōginen döyerdi, birmă̆ını birbirine vurerdi, nă̆ıllerde pādişah var, vezir var, erselen'iy belend boyı gedi var. baret_ăga, kemançesin çalerdi, gani xeyyat, kot_o şelvar tikerdi, geleli yem dam üstini suverdi, bu işleriy neticesi hereket, ellah özi hetmen verer bereket.

ellahekber, ereb aşbaz nèrdedi? merhum baret kemançesi kimdedi? xani aşbaz, çavuşli'de nèrdedi? meclisleri şirin_èdù gètdiler, özlerinnen xātireler ġoydıler. meherrem günleri mātem tuterdi, husèyn'in nōhesin muxtar dèyerdi, hesen boynu kesiğ şiven_aterdi, gel èy bād-i sebā, gèt kerbāle'ye, xeber vèr, fätime xéyru'l-nisāye.

goce, cevān bugün zencir vureller, tamam mātem tutub ġān ă̆liyeller, husèyn'in_ādine nōhe dèyeller, gereg dîn olmese dunyānı atmă̆g, şeref, izzetli bir dunyā yaratmă̆ .

fayton, atnen yuxaruden gelerdi, cebbar_oğlu, ġemçisiynen sürerdi, musāfirden ġeren yarmm alerdi,
Çeggırlı, ${ }^{31}$ yüreğime dar mıdır?

Yaradan onlara merhamet etsin, görelim, İşsizliği ve susuzluğu kessin, görelim.

Mestû Süpur, sokakları sulardı, Ferû Neccar, testeresini çekerdi, Gürüzlü de patlıcanı dökerdi, Helal lokma çıkarmaya çalışmak, Şirinliği yüreklere dökmek.

Nevruz Emmi, bize masal anlatırdı, Abguşst ${ }^{32}$ etini şevkle döverdi, Parmağını birbirine vururdu, Masallarda padişah var, vezir var, Erselen'in uzun boyu var.

Berat A ğa, kemençesini çalardı, Gani Heyyat, kot ve şalvar dikerdi, Köylü de dam üstünü sulardı, $\mathrm{Bu}$ işlerin neticesi hareket,

Allah'ın kendisi muhakkak verir bereket.

Allahuekber, Arap Aşpaz nerededir?

Eski baret "kemançe ${ }^{33 "}$ "si kimdedir?

Hani Aşpaz, Çavuşlu nerededir?

Meclisleri şirin edip gittiler,

Kendilerinden hatıralar koydular.

Muharrem günleri yas tutardı, Muhtar, Hüseyin'in ağıtını söylerdi, Hasan'ın boynunun kesilmesine feryat ederdi, Gel ey seher yeli, git Kerbela'ya,

Haber ver, hayırlı kadın Fatıma'ya.

Yaşlı, genç bugün zincir vururlar, Hepsi yas tutup kan ağlarlar, Hüseyin'in adına ağıt söylerler, Eğer din olmasa, dünyayı atmak gerek, Şerefli, izzetli bir dünya kurmak (gerek).

Fayton, at ile yukarıdan gelirdi, Cabbar oğlu, kamçısıyla sürerdi, Misafirden yarım "gıran ${ }^{34 "}$ alırdı,

\footnotetext{
${ }^{31}$ Köy ad1.

${ }^{32}$ Nohutlu et yemeği.
}

${ }^{33}$ Müzik aleti.

SEFAD, 2019; (41): 157-192 
ne bir günler kecçi, eceb görmedi, taksi geldi, fayton gètdi bilmedi.

(29)

deregez'iy tārixi çox ġedîmdi, bēzileri telxdi, bēzi şîrîndi, xorāsan'de dèyersen, bir gelindi, nuxandan' $\imath$, çavışlı'sı, gülriz'i, memmedābād, babacı̆̆ oniy gözi.

ellah ekber, bağde üzüm yı̆̆gerdi, sebed sebed on yerde sererdi, kişmiş_için bu zehmeti çekerdi, tomuzde ki zehmetleriy ucreti, giş gününde bu zehmetiy_izzeti. (31) derexlerde mekem dizăg gंurerdi, sar tutmağa, ne zehmetler çekerdi, $\dot{g} u s ̧$ vurmă̆a, şamal kimin üçerdi, ne kefflidi, sar tutmă̆den danışmă̆, refiğleri, dostleri bir yād_ètmă̆.

menuçèhr'nen bağde yonce yığerdi, cavād'inen medresede gülerdi, med rizā'ynen birbiri biz, vurerdi, dava ètmă̆, yı ̆̆lamă̆ler, géçdiler, her biri yem bir diyāre düşdiler.

çă̆alı̆̆iy ġoz_oynamă̆, günleri, aşşı̆̆, pāre, ġere gördüm günleri, gere gördüm, girg்i basan günleri, çă̆alı̆̆iy_oynamağ̆ı, ġaçmă̆ı, āyendeye sādeliğnen baxmă̆g.

mizande biz, körçe girdi oynerdi, giş günleri muzalaği vurerdi, tovlenerdi, baxerdi, kéf_èderdi,

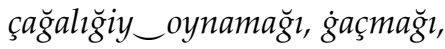
bu dōreni sur'etinen géçmă̆ı.

giş géceler mèhmānliğe gèderdi, fänus_elde, küçelerden kęçerdi, danışmă̆gden, āy meye biz, doyerdi,
Ne günler geçti, sanki görmedik,

Taksi geldi, fayton gitti anlamadık.

Deregez'in tarihi çok eskidir, Bazıları acıdır, bazıları şirindir, Horasan'da dersin, bir gelindir, Nuhandan'1, Çavuşlu'su, Gülriz'i, Muhammedabad, Babacığ onun gözü.

Allahuekber, bağda üzüm toplardık, Sepet sepet onu yerde sererdik, Kuru üzüm için bu zahmeti çekerdik, Yaz (mevsimi), zahmetlerin ücreti, Kış gününde bu zahmetin izzeti.

A ğaçlarda sağlam tuzak kurardik, Sı̆̆ırcık tutmaya ne zahmetler çekerdik, Kuş vurmaya, rüzgâr gibi uçardık, Ne keyifliydi, kuş tutmadan konuşmak, Arkadaşları, dostları bir yâd etmek.

Menuçehr ile bağda yonca yığardık, Cevat ile medresede gülerdik, Mehmet Rıza ile birbirimize vururduk, Dava etmeler, ağlamalar geçtiler, Her biri de bir diyara düştüler.

Çocukluğun ceviz oynama günleri, "Aşık, pare, kara gördüm ${ }^{35 "}$ günleri, "Kara gördüm, atmaca basan ${ }^{36 " ~ g u ̈ n l e r i, ~}$ Çocukluğun oynaması, kaçması, Geleceğe sadelikle bakması.

Sonbaharda biz, "körce girdi 37 " oynardik, Kış günleri topacı vururduk, Dönerdi, bakardık, keyiflenirdik, Çocukluğun oynaması, kaçması, Bu devreyi hızla geçmek.

Kış geceleri misafirliğge giderdik, Fanus elde, sokaklardan geçerdik, Konuşmaya meğer biz doyardık,

${ }^{34}$ Para birimi.

${ }^{35}$ Oyun adları.

${ }^{36}$ Oyun adları.

${ }_{37}$ Oyun adi. 
mèhmānlı̆̆l, ġoz, kişmişi, mîvesi, deneleri, çiyitleri, çitnesi.

(36) govurmeni xelteden çixererdi, cibe tökū, birbir on, yéyerdi, gahde onnen şorbe yem biz aserdi, şor gormeniy mezzesi yadlerdedi, govurǵeniy yémă̆g yadlerdedi.

kemerpüşde, kedi, garpuz goyerdi, çèlle gèce, yaxçı onı, keserdi, tamam birce, güle güle yèyerdi, giş gècesi, issi çayı, içerdi, neğil dèyū küreyleri açerdi.

bahar günler, bă̆leri bèlnen $\dot{g} a z m a \breve{g}$, pāybèleniy sessin erşe çixerma $\breve{g}$, gün çixennen ta batene, işlemă̆, tamam birce işlerdiler özleri, dèyerdiler, şirin şirin sözleri. gün çixennen yuvarçıler geleller, pāybèleni mekem yère vureller, yèri ġazū ekinleri ekeller, cemāatiy eli ele vérmă̆ birbiriniy dalınde berk durmağı.

(40)

her biri et getirerdi öziynen, gāabili yox dèyerdi öz diliynen, şād_èderdi üreyleri söziynen, xuday mèhri görerdi bendelerden, bereketi verrerdi xeznelerden. çopan_ă̆a pètavanı bağlerdi, goyunlernen dă̆gde daşde çaperdi, xèllik üste rahetliğnen yaterdi, baxerdi ki birden bir gurt gelmesin, goyunlere àsib, belā yètmesin.

péğ $\bar{u}$ ġaşmar, oră̆leri dişlerdi, küreni dağ ¿èdu işin başlerdi, dās_o teber, düzetmă̆çcin işlerdi, şāgèrdiynen sendene pük vurerdi, çay_içmă̆a ārede bir durerdi.

nuxandan'de sūlı dèrman işlerdi,
Misafirlik, ceviz, kuru üzüm, meyve,

Taneleri, çiğitleri ve (onların) kırılma sesi.

Kavurgayı torbadan çıkarırdık, Cebe döküp, tek tek onu yerdik, Bazen biz ondan çorba da yapardık, Tuzlu kavurganın tadı hatırlardadır, Kavurgayı yemesi hatırlardadır.

Kilere kabak, karpuz koyardık, Çille gecesi, onu güzelce keserdik, Hep birlikte, güle güle yerdik, Kış gecesi sıcak çayı içerdik, Masal anlatıp baklaları açardık.

Bahar günleri bağları bel ile kazmak, Küreğin sesini arşa çıkarmak, Güneş doğduktan ta batana kadar çalışmak, Hep birlikte çalışırlardı onlar, Söylerlerdi şirin şirin sözleri.

Güneş doğduktan sonra işçiler gelirler, Küreği yere sağlam vururlar, Yeri kazıp ekinleri ekerler, Cemaatin el ele vermesi, Birbirinin arkasında sağlam durması.

Her biri et getirirdi kendisiyle, Mümkün değil derdi kendi diliyle, Şad ederdi yürekleri sözüyle, Yaradan sevgiyi görürdü kullardan, Bereket verirdi hazinelerden.

Çoban ağa çarığını bağlardı, Koyunlarla dağda taşta koşardı, Kepeneğin üstünde rahatlıkla yatardı, Bakard1, birden bir kurt gelmesin, Koyunlara kötülük, bela gelmesin.

Peygamber demirci, orakları bilerdi, Ocağı yakıp işe başlardı, Orağı ve baltayı düzeltmek için çalışırdı, Çırağı ile örse balyoz vururdu, Çay içmeye arada bir dururdu.

Nuhandan'da sulu değirmen çalışırdı, 
dèrmançı hèy dāşın dişin dişlerdi, un tozinnen gözleri gaşlenerdi, bāre, zîne, buğgèleriy çüreyi, bu çüreyi durāğinen yémeyi.

erebeçi, erebeynen gelerdi, pambé̆g bu ğdè, erebeye üklerdi, yolleri o, yavaş yavaş géderdi, her gün seniy işiy tamam zehmetdi, xuday sene veren tamam rehmetdi.

(45)

küçe bă̆de şèru, bağden gelerdi, kerem derdi, esli'ni o seslerdi, dertli kerem, sözlerini söylerdi, her sebāh, her sebāh bulbuliy sesi, bāşıme vurıtdı yāriy hevāsı.

(46)

erzèrum'iy dāğ $\imath$ ġarı, bulă̆̆ géce gündüz, sesde olmă̆ gंulă̆ı, mecnun tekin yārden_almă̆ sorağ tomuziy issisi, gişiy eyazi, cānım aldı ġara gözleriy seniy. meniy_atam, kilasde ders vererdi, nāsir_ă̆a, çox yaxçı ders dèyerdi, $\dot{g} a \bar{h}$ şellağnen çă̆aleri vurerdi, medreseniy dersleri, yādeş bexxéyr, kitābinen defteri, yādeş béxèyr.

şād günleriy mehebbetli sözleri, cevan ġzler işillerdi gözleri, cevan, ġoce, şād_ıdıler özleri, selāmetliğ olar için ne erzān, amma bugün bizler için ne lerzān.

(49)

nuxandan'iy şeftalisi, alması, govun, ġarpuz, zerdalisi, alçası, gülleriniy rengi, oniy bağçesi, bir yuxu tek yādımdedi bă̆leri, bağlerinde ġiş günleri, ġarleri.

xatınleriy hammame gètmağleri, boğçelernen küçeden kęçmă̆leri, onnen, munnen üzlerin tutmă̆leri,
Değirmenci taşın dişini bilerdi, Undan ve tozdan gözleri kaşınırdı, "Bare, zîne ${ }^{38 "}$ buğdaylarının ekmeği, Bu ekmeği yoğurt ile yemesi.

Arabacı, arabayla gelirdi,

Pamuğu ve buğdayı arabaya yüklerdi, $\mathrm{O}$, yollarda yavaş yavaş giderdi,

Her gün senin işin tamamen zahmettir, Yaradan'in sana verdiği tamamen rahmettir.

Bağ yolundan Şir Ali gelirdi, Kerem'i söylerdi, Aslı'yı o seslerdi, Dertli Kerem, sözlerini söylerdi, Her sabah, her sabah bülbülün sesi, Başıma vurmuş yârin havası.

Erzurum'un dağı, karı, çeşmesi, Gece gündüz, seste olmak kulağı, Mecnun gibi yârden almak haberi, Yazın sıcağı, kışın ayazı,

Canımı aldı kara gözlerin senin.

Benim babam, sınıfta ders verirdi, Nasir ağa, çok güzel ders anlatırdı, Bazen değnekle çocuklara vururdu, Medresenin dersleri, hayırla anılsın, Kitabı ve defteri, hayırla anılsin.

Mutlu günlerin muhabbetli sözleri, Genç kızların ışıldardı gözleri, Genç, yaşlı mutluydular kendileri, Selametlik onlar için ne kolay, Ama bugün bizler için ne zor.

Nuhandan'ın şeftalisi, elması, Kavunu, karpuzu, zerdalisi, eriği, Güllerinin rengi, onun bahçesi, Bir uyku gibi hatırımdadır bağları, Bağlarında kış günleri, karları.

Kadınların hamama gitmeleri, Bohçalarla sokaktan geçmeleri, Ondan, bundan yüzlerini saklamaları, 
bu dastanler, kéçdi gètdi, ġutardl, köhne resmler, itdi gètdi, gutard.

(51) nenem meni hammama aparerdi, boxçemizi başınde götererdi, kise çekū yuverdi, çixererdi, xatınleriy sesi çixdi hamamde, kāte çă̆a, bu kimdi ser hamamde? nuxandan'iy hammamıniy xeznesi, issi suvu üste tökmă̆ mezzesi, kise çekū, temiz_olū çixmesi, kéçdi gètdi xātireler ġutardi, umur kéçdi, cevanlığler saraldı.

giş güninde vexti sovuğ deyerdi, xorzek_olū nefesimiz tuterdi, mama xanım boğzımızı baserdi, külli birmă̆ boğzımızı yarerdi, nefesimiz onnen söre gelerdi. gel, bir baxey kęçen géden günlere, bă̆de, atam zehmet çeken günlere, buğdè, pambiğ, teryey_eken günlere, terneleri, butteden biz üzerdi, dişe çekū tirpellerde ġaçerdi.

(55)

alacada belexene yixildi, derextdeki boy_ipi yem girildi, şirin şirin xātireler dă̆ıldı, bă̆da hovuz, daş torpă̆den dolıbdi, kāte çınār rîşesi yem itibdi.

(56) yuxarı teppeni göriy, dă̆ılıb, torpağleri küçelerde yayılıb, kōreleri bazarlerde satılıb, eger_olse bu teppeni saxlyyiy, keçenleri her neç̧eden yadlıyiy. meniy nenem, yaxçı layle dèyerdi, boyniç_ipin mekemliğnen çekerdi, yuxu mihri, üreyime tökerdi, nazlı nenem, laylaleriy tapermēn? bir de gene rāhetliğnen yatermēn? (58) men, nenemiy laylesiynen yaterdim,
Bu destanlar geçti gitti, tükendi,

Eski resimler, yitti gitti, tükendi.

Annem beni hamama götürürdü, Bohçamızı başında götürürdü, Çanta alıp yıkardı, çıkarırdı, Kadınların sesi çıktı hamamda, Büyük çocuk, bu kimdir hamamda?

Nuhandan'in hamaminin haznesi, Sicak suyu üste dökmenin tadı, Çanta çıkarıp, temiz olup çıkması, Geçti gitti hatıralar tükendi, Ömür geçti, gençlik sarardı.

Kiş gününde soğuk değerdi, Grip olup nefesimizi tutardık, Hanım anne boğazımızı okşardı, Bütün parmaklarıyla boğazımızı açardı, Nefesimiz ondan sonra gelirdi.

Gel, bir bakalım geçen giden günlere, Bağda, babamın zahmet çektiği günlere, Buğday, pamuk, haşhaş ektiği günlere, Kelekleri, daldan biz keserdik, Isırıp arklarda koşardık.

Bahçede kulübe yıkıldı, Ağaçtaki salıncak ipi de koptu, Tatlı tatlı hatıralar dağıldı, Bağda havuz, taş ve toprak ile dolmuş, Büyük çınarın kökleri de kaybolmuş.

Yukarı Tepe'yi görün, dağılmış, Toprakları sokaklarda yayılmış, Kiremitleri pazarlarda satılmış, Mümkünse bu tepeyi saklayın, Geçenleri zaman zaman yâd edin.

Benim annem, güzel ninni söylerdi, Beşiğin ipini sağlam çekerdi, Uyku sevgisini yüreğime dökerdi, Sevgili annem, ninnilerini bulur muyum? Bir de yine rahatlıkla uyur muyum?

Ben, annemin ninnisiyle yatardım, 
yuxu görū, ate minū çaperdim, yuxude öz ārézūmı taperdim, bulutleriy_içinde yol gèderdim, bulutlerden at düzetū minerdim.

(59)

meniy nenem kendiden un tökerdi, teşt_içinde onı yaxçı elerdi, xemir_èdū muşt vurmă̆a turerdi, keçdi gètdi, ġutarıtdı o günler, să̆ı solı sallanıtdı bu günler.

(60) méyèm çèrpi, tendire o tökerdi, otler dèyū kessū ele tuterdi, tendiri dă̆ $\dot{e} d \bar{u}$ çörey yaperdi, giş günleri tendirimiz $d \bar{a} \breve{g} \smile \imath d \imath$, küzeler_em tamam dolı yā̆g ¿ıdı.

zuveleni tendire o yaperdi, külinclerin ot_üstinnen tuterdi, çöreyleri eceb o yaraterdi, tendir_üste kekirleriy tezzesi, çă̆alerçin yèmă̆ıniy mezzesi.

xan nenemiy tendiriniy çöreyi, durāğinen bu çöreyiy yémeyi, céz̆̆aleni bu çöreye vurmeyi, tendir_üste gapdım_aldım tezzesin, yédim, gördim o çöreyin mezzesin.

garrı nene bă̆de şorbe aserdi, ot_üstinde mezzesine baxerdi, tèlit_èdü üstin o baserdi, o şorbeniy yèmă̆̆ yādeş bèxèyr, et, nuxutun doymağı yādeş béxéyr.

(64)

ate gètdi, nene yekke galıbdi, gör, özini ne bir güne salıbd,, cevanlı̆̆iy $\dot{g} u d r e t i n i$ atıbd,, bu dunyāye bèl bağlamă̆ olmèydi, feğet sabır yiğlamă̆nen bolmèydi.

(65) nenem, genem istim olim ġucă̆iyde, bacl, ġardaş_oley seniy ġ̀rağiyde, ne çāre ki varmız ${ }^{41}$ feğet sorağiyde,
Rüya görüp, ata binip koşardım, Rüyamda kendi dileğimi bulurdum, Bulutların içinde yol giderdim, Bulutlardan at yapıp binerdim.

Benim annem ambardan un dökerdi, Tekne içinde onu güzel elerdi, Hamur edip yoğurmaya kalkardı, Geçti gitti, bitti o günler, (Annem) sağa sola sallanır bugünlerde.

Meyem Çerpi, tandıra o dökerdi, Ateş yakıp eline bir odun aldı, Tandırı yakıp ekmek yapardı, Kış günlerinde tandırımız sıcaktı, Sürahiler de tamamen yağ ile doluydu.

Hamuru tandırda o pişirirdi, Pişenleri ateş üstünden alırdı, Ekmekleri sanki o icat ederdi, Tandırın üstünde "kekir"39"lerin tazesi, Çocuklar için yemenin tadı.

Annemin tandırının ekmeği, Yoğurtla bu ekmeği yemesi, "Cizgale $40 "$ yi bu ekmeğe sürmesi, Tandır üstünde kaptım aldım tazesini, Yedim, gördüm o ekmeğin tadını.

Büyükanne bağda çorba pişirirdi, Ateş üstünde tadına bakardı, Tirit edip üstüne basardı, O çorbanın yenmesi hayırla anılsın, Et, nohuda doyulması hayırla anılsın.

Baba öldü, anne yalnız kaldı, Gör, kendisini nasıl bir güne saldı, Gençliğin kuvvetini attı, Bu dünyaya bel bağlamak olmuyor, Fakat sabır ağlamakla bitmiyor.

Annem, gene isterim olayım kollarında, Bacı, kardeş olalım senin yanında, Ne çaremiz var, senin izinden (haberinden),

${ }^{39}$ Pişmiş ekmek.

${ }^{40}$ Pişmiş koyun kuyruğu. 
nenem, sene cānım ġurban, ha yèrdesen? izağ düşdüm yurdımızden, ha yèrdesen? (66) ellah ekber, nuxandan'iy toyleri, cevan_oğlan, cevan ġzler boyleri, gazan gazan et, pilow hoyleri, bir de gene o günleri göréydim, cevanleriy xoşlı̆̆ine gülèydim.

èlçi géderdi, èlçiliğ ¿èderdi, giz_almağa, başliğınnen dèyerdi, cevab ald $九$ kelle gendi düyerdi, yağlı̆̆deki kökeleri vèrerdi, ă̆ıleri şirin_èdü géderdi. mizan günü mehsuller ki yiğişdi, zāri' payı erbābınnen çixişdi, küreken em toy tutmağa barışdl, toyler birbir başlanerdi sāzinen, gelin gelerdi èvine nāzinen.

toy tutmağçin bend_o besat vār_ıd , mesleheti ad yazmă̆ havār ¿ıdı, et_o düyü, gab gazan acar_ıd $\imath$, däğden odun, hèyvanlernen gelerdi, teke, goyun, sürüden ayrlerdi.

(70) yuxartden carçi sesi gelerdi, tamam kesi toye xeber èderdi, yol yolağnen cariy sesin çekerdi, géce herkes toy yériye géderdi, noğul yèyib getimini ġoyerdi.

(71)

toy eyesi, mèhmānlerin bilerdi, et, düyüniy tedarikin görerdi, aşpaz, golın yuxarye vurerdi, yexni, pilov pişirmağgçin ġaçerdi, seher tėzden bu zehmetçin çaperdi.

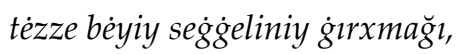
tar, gabalnen hammame aparmă̆̆l, dost_o refiğ, ārelerde gülmă̆g,
Annem, sana canım kurban neredesin?

Uzak düştüm yurdumuzdan neredesin?

Allahuekber, Nuhandan'ın düğünleri, Genç oğlanların, genç kızların boyları, Kazan kazan eti, pilavı, heyleri, Bir de yine o günleri göreydim, Gençlerin mutluluğuna güleydim.

Elçi giderdi, elçilik ederdi,

Kız almanın başlığından derdi,

Cevap alınca kelle şekeri kırardı, Mendildeki tatlıları verirdi,

Ağıları şirin edip giderdi.

Sonbaharda ürünler toplandı, Çiftçinin payı ortağından ayrıldı, Damat da düğün yapma firsatı buldu, Düğünler bir bir başlardı saz ile,

Gelin gelirdi evine naz ile.

Düğün için okuma vardı,

Davetlilerin adını yazmak zevkliydi,

Et ve düğü, kap kazan yeniydi,

Dağdan odun, hayvanlarla gelirdi,

Teke, koyun, sürüden ayrılırdı.

Yukarıdan tellal sesi gelirdi,

Bütün herkesi düğüne haber ederdi,

Merasimle tellal bağırırdı,

Gece herkes düğün yerine giderdi,

Şeker yiyip (para) hediyesini koyardı.

Düğün sahibi, misafirlerini bilirdi, Etin, düğünün tedarikini görürdü, Aşçı, kolunu kaldırırdı,

Yahni, pilav pişirmek için koşardı,

Sabah erkenden bu zahmet için koşard1.

Damadın sakalını tıraş etmek,

Enstrüman ve şarkıyla hamama götürmek,

Dost ve arkadaşın aralarda gülmesi,

41 ne çāre ki varmı < ne çāremiz ki var 'Ne çaremiz var.' İyelik ekinin yüklem pozisyonundaki var unsuruna getirildiği bu tür kullanımlar, Farsça "şahıs zamiri + isim + (ne)dār fiili + şahıs eki" diziminin etkisiyle ortaya çıkmıştır. Örneğin Farsça, mā xāne dārîm 'Evimiz var' cümlesinde olduğu gibi. Konu hakkında ayrıca bkz. Atıcı (2018).

SEFAD, 2019; (41): 157-192 
gördüm onde refiğleriy mèhrini, ġōm—o hişiy, yār yoldaşiy lutfinı.

(73)

cehiziye, xonçelerde eldedi, mis idişleri, cevanlernen yoldedi, sāzendeniy köki hetmen sendedi, ġab, ġazannen tă̆çeleri bezerdi, ref, divāre düzmeleri düzerdi.

toylerinde oxurduler özleri,

şad_olmăğçin çalerdiler sāzleri,

èimmeden dèyerdiler sözleri,

pèy̆̆emberiy ġzıni eli aldı yār yār,

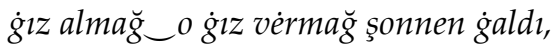
yār yār .

resmlerinde yār yār dèmă̆ vār $\_\imath d \imath$,

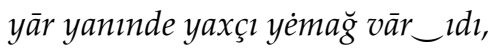

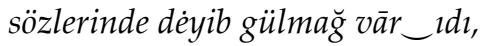
aftafade sū goydum, durulttdı yār yār, gédiy göriy, küreken, gül_olıtdı yār yār.

toy gècesi çal_o vurmă̆, oynamă̆, xatınleriy meclisinde oxumă̆, el defiynen kęçenlerden yérlemă̆, babacı"̆'iy üsti, mir'iy gelesi, gètdi, görükmedi yāriy ġeresi.

bir xatın oxurdı oğlan dilinnen, biri yem söylerdi gelin dilinnen, el defi, seslerdi aşı̆̆ dilinnen, bir heyat alıben hammame yaxin, hammamnen çixen çi boyıne baxım.

gelin bèli bağlanerdi şālinen, guran, çürey çülenerdi şālinen, nene birden bă̆ırerdi ġālinen, gelin yolı çalmă̆, yādlerden çixmes, yār yār dèmă̆ sesi, yādlerden çixmes.

gelinleriy bedov_ate minmesi, yār yārleriy belend sedāsi sesi, kürekeniy nārnen alma atması, yadden çixmes xatiredi, yādımde,
Gördüm o zaman arkadaşların sevgisini, Akrabanın, eşin, yoldaşın lütfunu.

Çeyiz, tepsilerde eldedir,

Bakır tabaklar, gençlerle yoldadır, Çalgıcıların düzeni muhakkak sendedir, Kap, kazan ile dolapları süslerdik, Rafa, duvara malzemeleri düzerdik.

Düğünlerde çağırırlardı onlar, Mutlu olmak için çalarlardı sazları, İmamlardan söylerlerdi sözleri, Peygamberin kızını Ali aldı yâr yâr, Kız almak ve kız vermek ondan kaldı, yâr yâr.

Düğünlerde yâr yâr demek vardı, Yâr yanında güzel yemek vardı, Sözlerinde deyip gülmek vardı,

Maşrapaya su koydum, duruldu yâr yâr,

Gidin görün, damat, gül oldu yâr yâr.

Düğün gecesi çalmak ve vurmak, oynamak, Kadınların meclisinde söylemek, El tefi ile geçenlerden konuşmak, Babacı '̆’n üstü, Mir'in kalesi, Gitti, gözükmedi yârin karası.

Bir kadın söylerdi oğlanın dilinden, Biri de söylerdi gelin dilinden, El tefi, seslerdi âşık dilinden, Bir ev aldım hamama yakın, Hamamdan çıktığında boyuna bakayım (diye).

Gelin beli bağlanırdı şal ile, Kur'an, ekmek sarılırdı şal ile, Anne birden bağırırdı feryat ile, "Gelin yolu42" çalmak, hatırlardan çıkmaz, Yâr yâr deme sesi, hatırlardan çıkmaz.

Gelinlerin "bedov43" ata binmesi, Yâr yârlerin yüksek sedası, sesi, Damadin nar ile elma atması, Hatırdan çıkmaz hatıradır, hatırımda,

42 Oyun havası adı.

43 Sağlam, küheylan at. 
gęçmişlerden menzeredi gözimde.

(80)

şir eli'niy yār yārleri, nefesi,

yāri géce çekerdi o nāz sesi,

şād_èderdi sözleriynen her kesi,

yuxarıden gelemen çekmemi çek yār yār, indi ğıziy, èrte men, içiyi çek yār yār.

toy günleri pilovleri süzende, selleleri bir kenarden düzende, mest cevanler iplerini üzende, toyde eceb velveler olerdi, goca, cevan belend belend gülerdi.

toylerdeki def, goşmeler yāddedi, ōliyāniy dūtarı, bax tağdedi, xatınleriy el defisi dildedi, kéçenleriy mehebbeti çox_ıdl, üreylerde kineleri yox_ıdr.

ġetim ġoymă̆ ne bir gözel resm—idi, mecmeleri dolandırmă̆ bezm—idi, pulı vèrū noğul yèmağ hezz_idi, ay bu resim ne bir gözel resm_idi, cevanleriy elin tutmağ husn_ıd. eyidlerde reyyet, xoşhāl_olerdi, lāle güli çölde, bağde çixerdi, yă̆ış, her gün bulutlerden yağerdi, xuday bizden mehebbetin alıbd, goca, cevan bextin gere yazıbd.

tamam yérde ġızler güli çixerdi, daş, dereler g̀rmiz donı giyerdi, üreyimiz mehebbetden dolerdi, hęç zātınan, üreyimiz şād ¿ıdı, mehebbetden çöl, dereler bā̆ğ $\imath d \imath$.

bezi iller, yağı̧ş eslen yağmesdi, ot, kem_idi; ineyler sağılmesdi, xuday, meye bu sahneye baxmesdi? çemçe gelin, bez_o belend seslerdi, xuday derrdi, yağı̧şi biz isterdi.
Geçmişlerden manzaradır gözümde.

Şir Ali'nin yâr yârleri, nefesi,

Yâri gece çekerdi o nazlı sesi,

Şad ederdi sözleriyle herkesi,

Yukarıdan geliyorum çizmemi çek yâr yâr,

Şimdi kızın, sonra ben, içini çek yâr yâr.

Düğün günleri pilavları süzünce,

Seleleri bir kenardan düzünce,

Mest gençler iplerini koparınca,

Düğünde ne velveleler olurdu,

Yaşlı, genç kahkahalarla gülerdi.

Düğünlerdeki tefler, koşmalar hatırdadır,

Çalgıcının sazı, bak dolaptadır,

Kadınların tefleri dildedir,

Geçenlerin muhabbeti çoktu,

Yüreklerde kinleri yoktu.

Hediye koymak ne güzel âdetti,

Tepsileri gezdirmek şenlikliydi,

Parayı verip şeker yemek zevkliydi,

Ah bu âdet ne güzel bir âdetti,

Gençlerin elini tutmak güzeldi.

Bayramlarda köylü, mutlu olurdu,

Laleler bahçede, tarlada çıkardı,

Yağmur, her gün bulutlardan yağardı,

Yaradan bizden sevgiyi almış,

Yaşlının ve gencin bahtını kara yazmış.

Bütün her yerde gelincikler çıkardı,

Taşlar, dereler kırmızı elbiseyi giyerdi,

Yüreğimiz sevgiyle dolardı,

Hiç kimsesiz, yüreğimiz mutluydu,

Sevgiden tarlalar, dereler bağdı.

Bazı yıllar, yağmur asla yağmazdı,

Ot, azdı; inekler sağılmazdı,

Yaradan, bu vaziyeti acaba görmez miydi?

"Çömçe gelin ${ }^{44 "}$ i süsleyip yüksek sesle haykırdık, Yaradan derdik, yağmuru biz isterdik.

44 Üzeri giydirilen bir değneğin "çömçe gelin" diye bağırılarak ev ev dolaştırılması şeklinde oynanan bir oyun. SEFAD, 2019; (41): 157-192 
çaxılerdi ildirimler ot kimin, duruşt doll, tökülerdi goz kimin, sèl gelerdi, sèl, avadan, dă̆ kimin, xeşst köpride durū one baxerdi, hèybetinnen, ġudretinnen ġaçerdi.

axır çerşenbe'niy yolı yolağı, ot_üstinnen ġuşler tekin kèçmă̆l,

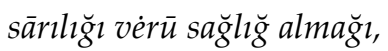
ay ne gözel menzeredi bu sehne, güller tekin görmelidi bu sehne.

eyidlerde āşı̆̆leriy çalmă̆ı, nuxandanlı xatınleriy yaşmağ pelvanleriy mèydande garmaşmağr, sînemaniy perdesi tek gözimde, hesreti var heniz_em üreyimde.

(90)

ellah ekber, eceb āşı̆̆ çalerdi, tiringini, g̀iş̧irigŭi salerdi, gelin $\dot{g} z \_$em kefter kimin üçerdi, yadiydedi çă̆alernen ġaçerdi, dam, bacadan xizlū eceb aşerdi.

gözel g̀ızler, boyleri sallardiler, boye minū g̀uş tekin üçerdiler, giş̧ģiriğnen boyleri üçerdiler, boy içmağiy lèzzeti, xoş kę̧̧mağl, yadımdedi çă̆alı̆̆de baxmă̆ $\imath$.

giz boyinen yuxarıden gelende, oğlan, çağa yağaçinen vurende, yār_adını bir dilinden alende, tamam birden çekerdiler helhele, gülmağinen düşerdi bir velvele.

axşam başı, āşı̆̆leriy çalmağı, pelvanleriy çuxe palter gèymağı, rustem tekin, méydan_içde gezmağ , ne bir ġeşeng sunnetdi bu ġarmaşmă̆, ġardaş tekin bir birinnen sallaşmă̆.

(94)

sizde güni at_erebe géderdi, piyādeler onnen tėzter yèterdi,
Çakardı yıldırımlar ateş gibi, İri dolu dökülürdü ceviz gibi, Sel gelirdi, sel, havadan dağ gibi, Tuğla köprüde durup ona baktık, Heybetinden, kudretinden kaçardık.

Son çarşambanın yolu yolağı, Ateş üstünden kuşlar gibi geçmek, Sarılığı verip sağlık almak,

Ay ne güzel manzaradır bu sahne, Güller gibi görmeye değer bu sahne.

Bayramlarda âşıkların çalması, Nuhandanlı kadınların başörtüsü, Pehlivanların meydanda mücadelesi, Sinema perdesi gibi gözümde, Hasreti var hâlâ yüreğimde.

Allahuekber, âşıklar güzel çalardı, Neşeyi, narayı salardı, Gelin kız da güvercin gibi uçardı, Hatırındadır çocuklarla koşardık, Damdan, bacadan hızlıca aşardık.

Güzel kızlar, salıncakları sallardılar, Salıncağa binip kuş gibi uçardılar, Nara ile salıncakları uçardılar, Sallanmanın lezzeti, hoş geçmesi, Hatırımdadır çocukluktaki koşmak.

Kız salıncakla yukarıdan gelince, Oğlan, çocuk ağaçla vurunca, Yâr adını bir dilinden alınca, Hepsi birden çekerdiler helhele, Gülmek ile düşerdi bir velvele.
Akşam başı, âşıkların çalması, Pehlivanların çuha elbise giymesi, Rüstem gibi, meydanda gezmesi, Ne güzel bir gelenektir bu yarışma, Kardeş gibi birbirini sallamak.
"Sizde günü45" at arabası giderdi, Yayalar ondan daha da tez ulaşırdı,

$\overline{45}$ Nevruzun 13. günü. Bu günde iyi bir yıl dileğiyle tabiata çıkılıp çeşitli etkinlikler gerçekleştirilir. 
hezret sultan bağlerinde durerdi, sizde güni, nehes çixermă̆ günidi, ġı, oğlanler bextin açen günidi.

(95)

sizde güni, hezret sultan çölinde, garmaşmă̆iy final méydan güninde, rustem tekin cevanleriy gözinde, eceb ġōgaler, var eceb fikirler, pelvan_olmă̆ için ne bir şükürler.

(96)

eyid gécesi, ocağleriy pilovu, ocağdeki yağaçleriy helovu, düyü saten tiḱkanleriy çelovu, girvanke daş, terezeden düşerdi, pilov, feğet eyid gècesi pişerdi.

eyid gécesi, nenem pilov pişirdi, sārı yă̆ı tökdi, meni ġ̀çırdı, gab, ġazanı ocă̆den o düşürdi, eyid pilovu mezzesi yadlerdedi, çă̆aleriy xoşlı̆̆ı yadlerdedi.

oğlanleriy sunnetiniy toyınde, usta musō elindeki tiğinde, keserdi o ustaliğnen yerrinde, gere, yaniğ letteleri yaperdi, yanmağıniy derdini toxdaderdi. (99)

babacı̆̆'iy yol, bir kem iză̆gd, merzi mekem, saxlamağa sayă̆dı, memleketçin ġedimnen bir dayağgd, babacı̆̆g'ım, lutfābād'ım ġālersēn? xarabliğden bir gün necāt tapersēn? (100)

babacı̆̆'de baratg்ulı vār ¿ıdı,

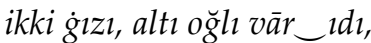

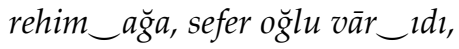
goca, cevan birbirine gatdiler, bax, ġabirde eceb rāhet yātdiler.

yūsif şeytan, tükleri āğarıtdı, merzden sü beri, kem bu yane kecçitdi, şèrim_emiy, bağıne sū tutıtdı, şorǵele'de axar suvu kesilitdi,
Hazreti Sultan bağlarında dururdu, "Sizde günü", uğursuzluğu çıkarma günüdür, Kızların, oğlanların bahtının açıldığı gündür.

"Sizde günü", Hazreti Sultan tarlasında, Yarışmanın meydanda final gününde, Rüstem gibi gençlerin gözünde, Ne kavgalar, ne fikirler var, Pehlivan olmaya çok şükür.

Bayram gecesi, ocakların pilavı, Ocaktaki odunların alevi, Düğü satan dükkânların pilavı, "Girvanke ${ }^{46 "}$ taşı, pencereden düşerdi, Pilav, sadece bayram gecesi pişerdi.

Bayram gecesi, annem pilav pişirdi, Tereyağını döktü, beni bağırttı, Kabı, kazanı ocaktan o düşürdü, Bayram pilavının tadı hatırlardadır, Çocukların mutluluğu hatırlardadır.

Çocukların sünnetinin düğününde, Usta Muso elindeki usturasında, Keserdi o ustalıkla yerinde, Kara, yanmış kumaşları yapıştırırdı, Yanmasının sızısını giderirdi.

Babacığ'ın yolu, biraz uzaktır, Sınırı sağlam, korumaya uygundur, Memleket için eskiden bir dayanaktır, Babacı̆̆'ım, Lutfabad'ım kalır misın? Harabelikten bir gün kurtulur musun?

Babacı '̆g'da Beratgulu vardı, İki kızı, altı oğlu vardı, Rahim Ağa, Sefer oğlu vardı, Yaşlıyı, genci birbirine kattılar, Bak, kabirde ne kadar rahat uyudular.

Şeytan Yusuf'un saçları ağarmış, Sınırdan bu tarafa, biraz su geçmiş, Şirim Emmi, bağına su tutmuş, "Şorgele ${ }^{47 "} \mathrm{de}$, akarsu kesilmiş,

${ }^{46}$ Ağırlık ölçüsü birimi.

${ }^{47}$ Köy adı.

SEFAD, 2019; (41): 157-192 
molla emim, eli elde galıtdt.

(102)

ġurban cevāhiri, niyāz nèrdedi? memmed_ettar'e bax, o ne yérdedi? lutfābād'iy sebzesi rūyādedi, ḱate ariğ, oniy suvu girritdi, tüninki çă̆a yem bugün murrıtdı.

sultan husin, hec yolıne gèdūdi, mekke yurtde birden nāxoş_olūdi, xèlasliğçin her yole o vurūdi, sağh̆ğ için şilg̀ān'e nezr ¿èdūdi, sultān-ı dîbāc'e o el atūdi.

birden biri one yavaş dèȳudi, xuday munde, sen şilgan'e gaçurdiy, amma cevāb bu tehr onnen $\_a l \bar{u} d i$, biz geribmiz, xuday bizi tanımes, o şahzāde, gonşıleri unutmes.

hatem gele, şilgāan hisār, lutfābād, sefer ġele, tog் ġi gazan, xéyrābād, şemsi xan_o mir ġele, ġeffarābād, tamam biri sūsızdıler bugünler, suvın gelib yètişmă̆ın gürüller?

(106)

memmed hesen ereb, dūtar çalende, şah senem'iy yārı dăğde galende, üreyimiz bu gisseden yanende, baxerdim ki onde ne bir nefes var, işitmağçin bizde heniz heves var.

şār şāreniy suvu bugün giurritdl, şir hovıziy şiri tèyden gopıtd,, murād teppe'deki daş_em ititdi, cevanlerim, sebzelerim soldiler, omrımızı yaman günde boldıler.

şilğan'deki imamzāde dîbāa'dı, mehebbeti bu millete sirācd, bāriğāhı, deregez'çin çirā $\breve{g} d \imath$, nuxandan'de ellāme şehristānı, iftixārî̀ mes' $\bar{u} d \hat{\imath}$, teftezānî.
Molla amcam, eli elde kalmış.

Gurban Cevahiri, Niyaz nerededir?

Mehmet Ettar'a bak, o ne yerdedir?

Lutfabad'ın sebzesi rüyadadır,

Büyük ark, onun suyu kurudu,

Dünkü çocuk da bugün yaşlıdır.

Sultan Hüseyin, Hac yoluna gitmişti, Mekke topraklarında birden hastalanmıştı, Kurtulmak için her yola başvurmuştu, Sağlık için "Şilgan"4"a adak adamıştı, Sultan Dibac'e o el açmıştı.

Birden biri ona yavaşça demişti, Yaradan burada, sen Şilgan'e kaçtın, Ama bu tür cevabı ondan almıştı, Biz garibiz, Yaradan bizi tanımaz, O şehzade, komşuları unutmaz.

Hatem Kale, Şilgan Hisar, Lutabad, Sefer Kale, Toggi Gazan, Hayrabad, Şemsi Han ve Mir Kale, Gaffarabad, Hepsi birden susuzdurlar bugünler, Su gelip yetişir mi, gürülder mi?

Mehmet Hasan Arap, sazı çalınca, Şah Sanem'in yâri dağda kalınca, Yüreğimiz bu kıssadan yanınca, Bakardım ki onda nasıl bir nefes var, Dinlemek için bizde hâlâ heves var.

Şelalenin suyu bugün kurudu, Büyük havuzun musluğu koptu, Murat Tepe'deki taş da kayboldu, Gençlerim, sebzelerim soldular, Ömrümüzü zor günlerde bitirdiler.

Şilgan'daki İmamzade Dibac'dır, Muhabbeti bu millete açıktır, Makamı, Deregez için ışıktır, Nuhandan, âlimler şehri, İftiharlı Mesudî, Teftazanî ${ }^{49}$.

${ }^{48}$ Köy adı. İmamzade Dibac'ın mezarı o köydedir. ${ }^{49}$ Mesudî ve Teftazanî, Deregez' in iftihar vesilesi iki âlimdir. 
babacı"̆'den gèden gètdi, kim galdī? ölen_öldi, iten_itdi, kim galdì? köçen köçdü, cemaatı azaldì? olar bir gün äbād_olsun şehrimiz? xarablı̆gden xèlās_olsun yurdımız?
Babacı'̆' dan giden gitti, kim kaldı?

Ölen öldü, yiten yitti, kim kaldı?

Göçen göçtü, cemaati azaldı mı?

Bir gün abat olur mu şehrimiz?

Harabelikten kurtulur mu şehrimiz? 


\section{3-SÖZLÜK}

\begin{tabular}{|c|c|c|c|}
\hline $\begin{array}{l}\text { acar } \\
\text { aftafa }\end{array}$ & $\begin{array}{l}\text { : Yeni. } \\
\text { : Masrapa. }\end{array}$ & cèzğale & $\begin{array}{l}\text { : Pişmiş koyun } \\
\text { kuyruğu. }\end{array}$ \\
\hline axir çerşenbe & : Son Carsamba. & cib & : Cep. \\
\hline alaca & : Bahçe. & çağa & : Çocuk. \\
\hline alça & : Erik. & çağalı̆̆ & : Çocukluk. \\
\hline apar- & : Götürmek. & çap- & : Koşmak. \\
\hline $\bar{a}$ sib & : Kötülük. & çekme & : Çizme. \\
\hline aşpaz & : Aşçı. & çelov & : Pilav. bk. pilov. \\
\hline aşşağa & : Aşağı. & çèlle & : Çille (yılın en uzun \\
\hline aşşı̆ & : Oyun adı. & & gecesi). \\
\hline ata & : Baba. & çėmçe gelin & : Üzeri giydirilen bir \\
\hline āyende & : Gelecek. & & değneğin “çömçe \\
\hline badımcan & : Patlican. & & gelin" diye bağırılarak \\
\hline bāre & : Buğday çeşidi. & & ev ev dolaştırılması \\
\hline barış- & : Firsat bulmak. & & şeklinde oynanan bir \\
\hline bazar & : Pazar. & & oyun. \\
\hline bedov & : Sağlam, küheylan at. & çırāğg & : Lamba, 1şık. \\
\hline bext & : Baht. & çix- & : Çıkmak. \\
\hline belexene & : Kulübe. & çixar- & : Çıkarmak. \\
\hline belend & : Yüce. & çirāğ & : Işık. \\
\hline bende & : Kul. & çitne & : Yemişlerin kırılma \\
\hline \multirow[t]{2}{*}{ bend_o besat } & : Düğüne okuma & sesi. & \\
\hline & (davet etme). & çiyit & : Çiğit (yemiş adı). \\
\hline besteni & : Dondurma. & çopan & : Çoban. \\
\hline bēzi & : Bazı. & çöl & : Tarla. \\
\hline bèḱarlı̆ & : İşsizlik. & çülen- & : Bağlanmak. \\
\hline bèl & : Bel. & çürey & : Ekmek. \\
\hline bîxed & : Sinırsiz. & dād çek- & : Bağırmak. \\
\hline birce & : Birlikte. & dağ _èt- & :Yakmak. \\
\hline birmağ & : Parmak. & dal & : Arka. \\
\hline boğçe & : Bohça. & danış- & : Konuşmak. \\
\hline \multirow[t]{2}{*}{ bol- } & : Olmak; bitmek, & dās & : Orak. \\
\hline & bitirmek, sona ermek. & dastan & : Destan. \\
\hline boy & : Salıncak. & daş & : Taş. \\
\hline boyniç & : Beşik. & dayağ & : Dayanak. \\
\hline buğdè & : Buğday. & def & : Tef (çalg1 aleti). \\
\hline bulağ & : Çeşme. & dene & : Tane (yemiş adı). \\
\hline bulbul & : Bülbül. & derext & : Ağaç. \\
\hline butge & : Büfe. & ders dè- & : Ders anlatmak. \\
\hline butte & : Dal. & dey- & : Değmek. \\
\hline carçi & : Tellal. & dèrman & : Değirmen. \\
\hline cehiziye & : Çeyiz. & dèrmançı & : Değirmenci. \\
\hline cevan & : Genç. & dişe çek- & : Isırmak. \\
\hline cevanlı̆̆ & : Gençlik. & dizağ & : Tuzak. \\
\hline
\end{tabular}




\begin{tabular}{|c|c|c|c|}
\hline don & : Elbise. & gerib & : Garip. \\
\hline dōre & : Devre, dönem. & getim & : Dügüunde verilen para \\
\hline dov & : Vadi. & & hediyesi. \\
\hline durāğg & : Yoğurt. & gemçi & : Kamçı. \\
\hline durust & : Dürüst. & geşeng & : Güzel. \\
\hline durustliğ & : Dürüstlük. & geyne- & : Kaynamak. \\
\hline duruşt & : İri. & gèsse & : Kissa. \\
\hline dūtar & : Saz. & ġ1rağ & : Yan, kenar. \\
\hline düzet- & : Düzeltmek. & ġırmız & : Kırmızı. \\
\hline düzme & : Mutfak malzemesi. & ġıler güli & : Gelincik (çiçek adı). \\
\hline eceb & : Sanki. & girg̈i & : Kartal. \\
\hline ellahekber & : Allahuekber dağı. & girg̈i basan & : Oyun adi. \\
\hline \multirow[t]{2}{*}{ em } & : Da de (pekiştirme & gisse & : Kıssa. \\
\hline & edatı). bk. yem. & giş & : Kış. \\
\hline emi & : Amca. & ġişġiriğ & : Naea. \\
\hline erebe & : Araba. & goce & : Koca, ihtiyar. \\
\hline erzān & : Kolay. & gōòga & : Kavga. \\
\hline eslen & : Asla. & ḡōm_o hiş & : Akraba. \\
\hline eyaz & : Ayaz. & ġonş1 & : Komşu. \\
\hline eyid & : Bayram. & gorme & : Kavurga. bk. \\
\hline èimme & : İmam. & & ġovurme. \\
\hline feryād çek- & : Feryat etmek, & govurme & : Kavurga. bk. ġorme. \\
\hline bağırmak. & & $\dot{\text { goz }}$ & : Ceviz. \\
\hline gez yağacı & : Bir tür ağaç. & goze & : Kabuk. \\
\hline girvanke & : Ağırlık ölçü birimi. & gucalığ & : Yaşlı1ık. \\
\hline göter- & : Götürmek. & gulle & : Tepe. \\
\hline gabal & : Şarkı. & ġurrı- & : Kurumak. \\
\hline ġābil & : Mümkün. & gutar- & : Bitmek, tükenmek. \\
\hline gahde & : Bazen. & hammam & : Hamam. \\
\hline g̀āl & : Feryat. & havār & : Zevkli. \\
\hline \multirow[t]{2}{*}{ ġarmaş- } & : Mücadele etmek, & hec & : Hac. \\
\hline & yarışmak. & heniz & : Hâlâ. \\
\hline garrı nene & : Büyükanne. & hereket & : Hareket. \\
\hline ġarpuz & : Karpuz. & hetmen & : Muhakkak. \\
\hline gaşlen- & : Kaşınmak. & hevā & : Hava. \\
\hline ġaşmar & : Demirci. & heyat & : Ev. \\
\hline ġatığ & : Yoğurt. & hez & : Zevk. \\
\hline ġaz- & : Kazmak. & hèyret & : Hayret. \\
\hline ged & : Boy. & hov1z & : Havuz. \\
\hline gedim & : Eski zaman, kadim. & hudāvend & : Yaradan. \\
\hline g̀elb & : Kalp. & husn & : Güzel. \\
\hline gelyan & : Nargile. & xarablı̆̆ & : Harabelik. \\
\hline gend & : Şeker. & xatın & : Kadın. \\
\hline gere & : Kara. & xātire & : Hatıra. \\
\hline gere gördüm & : Oyun adı. & xemir & : Hamur. bk. zuvele. \\
\hline geren & : Para birimi. & xezne & : Hazine. \\
\hline
\end{tabular}




\begin{tabular}{|c|c|c|c|}
\hline $\begin{array}{l}\text { xèlaslı̆̆ } \\
\text { xẻlās_ol- } \\
\text { xẻllik }\end{array}$ & $\begin{array}{l}\text { : Kurtuluş. } \\
\text { : Kurtulmak. } \\
\text { : Kepenek (çoban } \\
\text { giysisi). }\end{array}$ & $\begin{array}{l}\text { küze } \\
\text { kölge } \\
\text { körçe girdi } \\
\text { kötel }\end{array}$ & $\begin{array}{l}\text { : Sürahi. } \\
\text { : Gölge. } \\
\text { : Oyun adı. } \\
\text { : Tepe. }\end{array}$ \\
\hline xèşt & : Tuğla. & küçe & : Sokak. \\
\hline xèyar & : Salatalık. & küfle- & : Üflemek. \\
\hline xẻyru'l-nisā & : Hayırlı kadın. & küre & : Ocak. \\
\hline xonçe & : Tepsi. & kürey & : Bakla. \\
\hline xorzek & : Grip. & layle & : Ninni. \\
\hline xoşallı̆ & : Mutluluk. & lerzān & : Zor. \\
\hline xoşhāl & : Mutlu. & lette & : Kumaş. \\
\hline xuday & : Yaradan. & maşın & : Araba. \\
\hline igit & : Yiğit. & mecme & : Tepsi. \\
\hline ikki & : İki (2). & mehebbet & : Muhabbet. \\
\hline il & :Y11. & meherrem & : Muharrem (kutsal ay \\
\hline ildirim & : Yildırım. & & ad1). \\
\hline iney & : İnek. & mehsul & : Ürün. \\
\hline issi & : Koku. & mekem & : Muhkem, sağlam. \\
\hline işille- & : Işıldamak. & merz & : Sinir. \\
\hline işle- & : Çalışmak. & meye & : Meğer. \\
\hline it- & : Kaybolmak. & mezze & : Lezzet, tat. \\
\hline izağ & : Uzak. & mèhmān & : Misafir. \\
\hline ḱasıb & : Esnaf. & mèhmānlı̆̆ & : Misafirlik. \\
\hline ḱasıblı̆ & : Esnaflık. & mèhr & : Sevgi. \\
\hline ḱāte & : Büyük. & min- & : Binmek. \\
\hline kedi & : Kabak. & mis idiş & : Bakır tabak. \\
\hline kefter & : Güvercin. & mîve & : Meyve. \\
\hline kekir & : Pişmiş ekmek. & mizan & : Sonbahar. \\
\hline kem & $: \mathrm{Az}$ & musāfir & : Misafir. \\
\hline kemançe & : Kemençe. & muşt vur- & : Yoğurmak. \\
\hline kemerpüş & : Kiler. & muzalağ & : Topaç. \\
\hline kendi & : Ambar. & nādurusliğ & : Sahtekârlık. \\
\hline kes & : Kişi, kimse. & nağıl & : Masal. \\
\hline kèç- & : Geçmek. & necāt tap- & : Kurtulmak. \\
\hline kèf_èt- & : Keyiflenmek. & nehes & : Uğursuzluk. \\
\hline kèfli & : Keyifli. & nene & : Anne. \\
\hline kiçiliğ & : Çocukluk. & nezr_èt- & : Adak adamak. \\
\hline kilas & : Sinif. & nèçe & : Nasıl. \\
\hline kimin & : Gibi (çekim edatı). & noğul & : Şeker. \\
\hline kîne & : Kin. & nōhe & : Ağıt. \\
\hline kise & : Çanta. & nuxut & : Nohut. \\
\hline kişmiş & : Kuru üzüm. & oxu- & : Şarkı söylemek. \\
\hline ḱōre & : Kiremit. & olar & : Onlar. \\
\hline köhne & : Eski. & orağ & : Orak. \\
\hline köke & : Tatlı. & ot I & : Ot. \\
\hline küreken & : Damat. & ot II & : Ateş. \\
\hline
\end{tabular}




\begin{tabular}{|c|c|c|c|}
\hline oyan- & : Uyanmak. & şār şāre & : Şelale. \\
\hline$\ddot{o z z}$ & : Kendisi. & şelvar & : Şalvar. \\
\hline palter & : Elbise. & şîven_at- & : Feryat etmek. \\
\hline pambėğ & : Pamuk. & şōg & : Şevk. \\
\hline pāre & : Oyun adi. & şorbe & : Çorba. \\
\hline pāybèlen & : Kürek. & tağ $\sim$ tağçe & : Dolap. \\
\hline pelvan & : Pehlivan. & tamam & : Bütün, hep. \\
\hline pèğ $\bar{u}$ & : Peygamber. & tamaşa & : Temaşa, seyir. \\
\hline pètavan & : Çarık. & tap- & : Bulmak. \\
\hline pilov & : Pilav. bk. çelov. & tar & : Enstrüman. \\
\hline piyade & : Yaya. & teber & : Balta. \\
\hline pul & : Pul. & tehr & : Tür, çeşit. \\
\hline pük & : Balyoz. & tekin & : Gibi (çekim edatı). \\
\hline ref & : Raf. & telx & : Acl. \\
\hline refi $\breve{g}$ & : Arkadaş. & teppe & : Tepe. \\
\hline rehm & : Rahîm, merhametli. & tereze & : Pencere. \\
\hline rehmet & : Rahmet. & terne & : Kelek (yiyecek adı). \\
\hline resm & : Düğün, âdet. & teryey & : Haşhaş (yiyecek adı). \\
\hline reyyet & : Köylü. & teşt & : Tekne. \\
\hline rîşe & : Kök. & tezze & : Taze. \\
\hline sar & : Siğırcık. & tèlit & : Tirit. \\
\hline saral- & : Sararmak. & tèzter & : Daha hizlı. \\
\hline sarèmsağ & : Sarımsak. & tiğ & : Ustura. \\
\hline sārı yağ & : Tereyağı. & tiḱan & : Dükkân. \\
\hline sayağ & : Uygun, münasip. & tiringi & : Neşe. \\
\hline sebāh & : Sabah. & tirpel & : Ark. \\
\hline sebed & : Sepet. & toxdat- & : İyileştirmek. \\
\hline sebzi & : Sebze. & tōle- & : Döndürmek, \\
\hline seg்g̀el & : Sakal. & & kivirmak. \\
\hline selle & : Sele. & tomuz & : Yaz (mevsim adı). \\
\hline senden & : Örs. & torpağ & : Toprak. \\
\hline ses çek- & : Bağırmak. & tovlen- & : Gezmek, dolaşmak. \\
\hline sibil & : Biyık. & tovlı & : Kivrimli. \\
\hline sizde güni & : Nevruzun 13. günü. & toy & : Düğün. \\
\hline sorăg & : Haber. & toy tut- & : Düğün yapmak. \\
\hline sovuğ & : Soğuk. & tök- & : Dökmek. \\
\hline söre & : Sonra (çekim edatı). & tuḱan & : Dükkân. \\
\hline$s \overline{\mathbf{u}}$ & : Su. & tük & : Tüy. \\
\hline sūlı & : Sulu. & tüninki & : Dünkü. \\
\hline sunnet & : Sünnet. & ucret & : Ücret. \\
\hline sur'et & : Hiz. & umur & : Ömür. \\
\hline suve- & : Sulamak. & üç- & : Uçmak. \\
\hline şād_èt- & : Şad etmek. & ükle- & : Yüklemek. \\
\hline şāgèrd & : Çırak. & üreg ürey & : Yürek. \\
\hline şamal & : Rüzgâr. bk. şamali. & $\ddot{\mathbf{u z}}$ & : Yüz. \\
\hline şamali & : Rüzgâr. bk. şamal. & üz- & : Koparmak. \\
\hline
\end{tabular}




\begin{tabular}{|c|c|}
\hline üzim & : Üzüm. \\
\hline üzlen- & : Bakmak. \\
\hline vere $\breve{g}$ & : Sayfa. \\
\hline yādeş bèxèyr & : Hayırla anılsın. \\
\hline yadla- & : Hatırlamak. \\
\hline yağaç & : Ağaç. \\
\hline yağlı̆ & : Mendil. \\
\hline yaxçı & : Güzel. \\
\hline yap- & : Yapıştırmak. \\
\hline yexni & : Yahni. \\
\hline yekke & : Yalnız. \\
\hline yem & $\begin{array}{l}\text { : Da de (pekiştirme } \\
\text { edatı). bk. em. }\end{array}$ \\
\hline yèrle- & : Konuşmak. \\
\hline yığla- & : Ağlamak. \\
\hline yiğiş- & : Toplanmak. \\
\hline yonce & : Yonca. \\
\hline yuxu & : Uyku. \\
\hline yuv- & : Yikamak. \\
\hline yuvarçı & : İşçi. \\
\hline zāri' & : Çiftçi. \\
\hline zat & : Şey. \\
\hline zebān & : Dil. \\
\hline zehmet & : Zahmet. \\
\hline zîne & : Buğday çeşidi. \\
\hline zuvele & : Hamur. bk. xemir. \\
\hline
\end{tabular}

